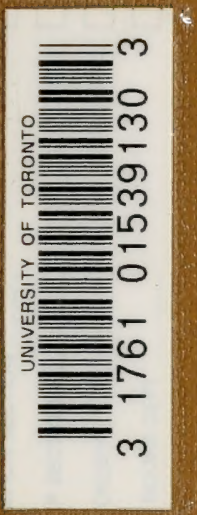


Digitized by the Internet Archive in 2007 with funding from Microsoft Corporation 


COMMERCIAL FORESTRY IN BRITAIN ITS DECLINE AND REVIVAL 
BY THE SAME AUTHOR.

\section{BRITISH FORESTRY}

ITS PRESENT POSITION AND OUTLOOK AF'ER THE WAR. 6s. net

"Mr. Stebbing writes with authority. He has had experience in other countries, and he is now Master of Forestry in Edinburgh University. $\mathrm{He}$ knows what is wrong, as many others know, and his book is written in the hope that it will add strength to the effort now being made to restore to these islands the industry of timber growing. . . . He puts the case extremely well, and he puts it with moderation."-The Field.

\section{LONDON : JOHN MURRAY}





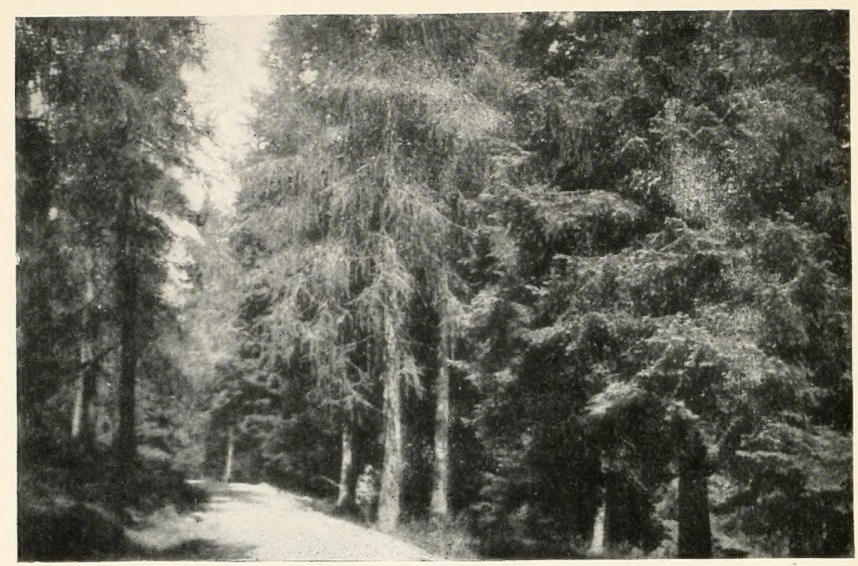

OLd WOOdS STANDING BEFORE THE WAR.

Craig Vivian old larch and spruce woods, Atholl Estates, Perthshire.

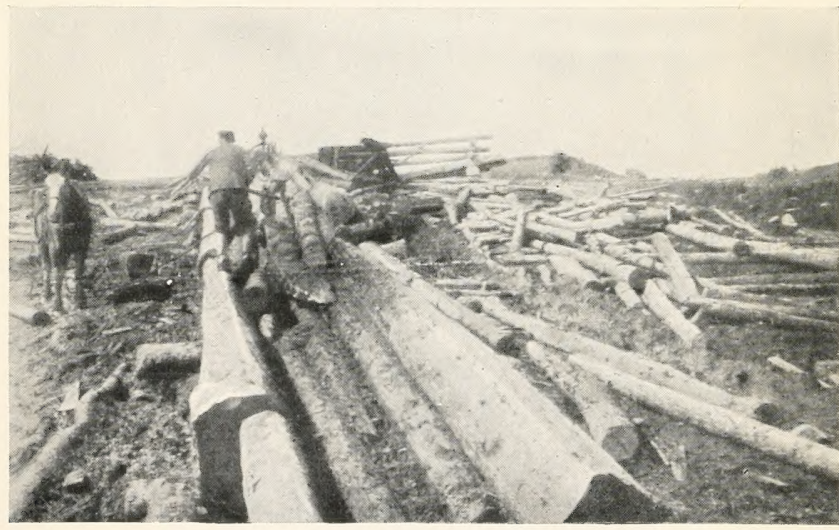

Same Area in July igi 8.

[Frontispiece 


\title{
COMMERCIAL FORESTRY IN BRITAIN
}

ITS DECLINE AND REVIVAL

\author{
BY E. P. STEBBING \\ HEAD OF THE DEPARTMENT OF FORESTRY \\ UNIVERSITY OF BDINBURGH
}

WITH FRONTISPIECE

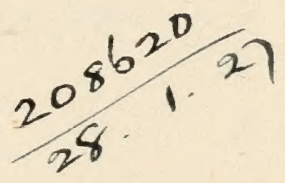

LONDON

JOHN MURRAY, ALBEMARLE STREET, W. 1919 


$$
\begin{aligned}
& \text { AaL Rrours RessRvgd } \\
& \text { SD } \\
& 179 \\
& 575
\end{aligned}
$$




\section{CONTENTS}

\section{INTRODUCTION}

PAGB

FORESTS: THEIR DIRECT AND INDIRECT UTILITY TO A NATION • • . I I

\section{PART I \\ THE PAST}

ARTICLE

I. FORESTRY IN GREAT BRITAIN IN EARLY TIMES

II. FORESTRY IN GREAT BRITAIN IN LATER TIMES • • . . . . 23

III. THE REVIVAL OF FORESTRY IN GREAT BRITAIN • • • • • 32

\section{PART II \\ THE WAR PERIOD}

IV. TIMBER SUPPLIES DURING THE WAR - 53

V. THE AFFORESTATION PROBLEM DURING THE WAR

69 


\section{PART III \\ THE FUTURE}

ARTICLE

VI. BRITAIN AND EUROPE'S TIMBER REQUIREMENTS

VII. WHAT AFFORESTATION WILL DO FOR THE PEOPLE . . . . . . . IOO

VIII. WHAT AFFORESTATION WILL DO FOR THE

NATION • . . . . . . I06

IX. FORESTRY AND AGRICULTURE • . II2

X. THE PROTECTION OF THE AFFORESTED AREAS . . . . . . I2I

XI. FORESTRY EDUCATION . • . . I40

XII. STATE OWNED VERSUS PRIVATELY OWNED FORESTS . . . . . . 148

XIII. THE AFFORESTATION SCHEMES . . I62

XIV. SUMMARY OF CONCLUSIONS • • • I75 INDEX - . . . . . I83 


\section{INTRODUCTION}

FORESTS: THEIR DIRECT AND INDIRECT UTILITY TO A NATION

THE utility of forests to a nation is one of the economic factors to its well-being which has been brought to an unforeseen and unexpected prominence during the waging of the World War. And perhaps to no other European nation has this unlooked-for development proved so startling, because so totally unexpected, as to ourselves. Forestry in its general aspects as it affects our country both in peace and war is a branch of economic industry of which the British public has known very little in the past. And it is perhaps not surprising that they should have remained in ignorance of its importance. For we have no forests in Britain in the sense in which the forest is understood in Europe and elsewhere in the world. We have woodlands, and exceedingly pretty they are, as we all know. From the point of view of the picturesque few things are more beautiful than the British woodland, with its old gnarled trees or tapering heavily branched firs and pines and larches; its open glades revealing stretches of greensward, of bracken, or a tangle of bramble, brier, 
honeysuckle, and so on; the beautiful copses so common in Britain,-they all hold a place of their own in our hearts. But the raison d'être of these woodlands has been primarily connected with providing shelter for the crops or stock of the farm, for sport or for amenity purposes. They are a part of our country, of ourselves, and there is no reason why they should not remain with us in reason. But we did not think it necessary to grow woods for purely commercial reasons-that is, for the sake of the timber and pit wood and paper pulp they would yield. We obtained our requirements of these commodities by importing them from abroad, and relied on the Navy being able to safeguard these imports.

And we discovered too late that we were living in a fool's paradise of our own construction. The nation'as a nation had forgotten all its forefathers had known about forestry; and even if they had not done so, much of that knowledge would have proved useless to them, for modern requirements and conditions have to a great degree completely changed.

Now, it is useless to expect a public opinion to form amongst a people and harden into a temper which will see that it obtains what it realizes to be an obvious economic need-a necessity for its wellbeing, even its preservation-unless that opinion has been formed by a matured understanding of its requirements. In this question of forestry such a public opinion has been entirely lacking in the past. No effort, no genuine widespread effort, has been made to establish such an opinion. It is true 
that the arboricultural societies of the country have done what they could; but their exhortations were chiefly confined to, or mainly reached those more or less connected with forestry matters in this country, proprietors of woods, their employees, agents, factors and foresters, and timber merchants, the latter's chief interest lying in purchasing and felling the woods. The mass of the people could, in the ordinary nature of things, never have heard of these exhortations and remain unaffected thereby. And let it be said at once that those who preached had not, could not have had, an inkling of how vital and serious this problem was to become. As will be shown, the governments who have held office during the past quarter of a century dallied with the question, but they, no more than the public-or it would perhaps be more correct to say, because of the apathy of the public-were without faith in the importance of the forestry problem, and even questioned the necessity of the existence of such a problem as an economic factor in the national interests.

There was a slow commencement of a revival of the question just previous to the outbreak of the war, but it is an open secret that the Government were still far from thoroughly convinced of the urgency of the afforestation question. And at that date but an infinitesimal fraction of the public had ever heard of it ; and the ideas amongst this fraction as to the manner in which the problem should be tackled could not by the strongest effort of imagination be described as clear cut or unanimous. 
It is scarcely a matter for surprise, therefore, that when the war-cloud burst over Europe this country from the forestry point of view, was totally unprepared.

What was the result? Both Government and public were equally amazed, it may be said dumbfounded, to discover that there was something in this forestry problem; and that it was going to prove, or the absence of timber supplies in the country was going to prove, a most troublesome thorn in the management of one side of the war. But the war has done more. For it has brought home to Government and public alike the realization that the aims and objects of forestry and its economic importance to the country were a sealed book to both.

Let us consider this aspect of the matter briefly. What are these aims, and what is the utility of the forest to a nation in the stress of war and in times of peace?

Both, it was thought, were well understood on the Continent of Europe before the war. But an examination of continental text-books on the subject discloses the fact that so far as war, modern war, is concerned, even on the Continent the value of the forest and its close connection with the operations of the contending armies was but dimly foreseen. Large areas of forest would form a good protective land frontier to a nation and would provide firewood for the troops. These were considered to be their chief military value. Perhaps in the archives of the German War Staff it may be recorded that an 
exceptionally large demand for timber might prove one of the factors to the successful waging of a great war. But it is doubtful whether even the German Head-Quarter Staff foresaw the gigantic demand on the forest to supply the materials required for trenches, light railways, and so on which this war has witnessed. And even if they did realize it to some extent, their argument would have been that they would obtain their requirements in this respect from the countries they overran; and this has been borne out by the facts, as Belgium, North France, Poland, and elsewhere in the fighting areas amply demonstrate. But the French we know for a fact did not anticipate this enormous demand for forestry materials. Even after the war had been in progress for some length of time, and the great shortage of wood was becoming apparent, they were unwilling to sacrifice their fine forests. And the effort to preserve them was a very natural and laudable one. But it could not be persisted in, and by the third year of the war heavy felling had to be made in their forests in the interests of the common cause.

What is the result of all this to us as a nation? What object lesson does it hold for us? What is the real utility of the maintenance of a proportion of a nation's land under commercially managed woods? Until the answers to these questions are grasped by the British public; until that public is educated to the point when the man in the street could give you a correct answer to such a question, real progress in this forestry problem as applicable to our country cannot be looked for. 


\section{UTILITY OF FORESTS TO A NATION}

And the war has demonstrated that it is an economic factor of undeniable importance to Great Britain.

Broadly speaking, the utility of the forest to the Nation may be grouped under two main headsdirect utility and indirect utility.

The direct utility of the forest is dependent upon the produce which it yields, the capital it represents, and the amount of labour it employs. For our purposes the chief produce of the forest is timber and pit wood, followed by wood pulp, packing-case wood, wood used for turnery purposes, bobbins, and so on. But the forest may also yield a variety of minor or secondary produce, such as pitch, tar, oil of turpentine at home, and caoutchouc, gutta-percha, rosin, gums, dyes, lac, etc., in other parts of the Empire, of which between $f_{14}, 000,000$ and $\ell_{15}, 000,000$ sterling were imported into this country in I9I3. Of the chief products, timber and pit wood, the war has brought home to us our almost entire dependence on imports for our supplies. It has also demonstrated that, in spite of all the substitutes which have replaced wood in construction and other industries, wood is as necessary to us in this twentieth century as it has ever been in past history-if not more so. For one thing, new industries consuming wood have arisen, e.g. the wood-pulp trade and, a newer one, the aeroplane industry. The total value of the forest produce used in the industries of Europe alone in I9I3 was probably somewhere between $£ 230,000,000$ and $£ 240,000,000$. The war has also proved, as no war has ever done before, that a nation cannot with safety depend entirely on imports for its timber, 
etc., requirements. That the interests of national security, let alone national economy, demand that a certain amount of this material should be grown at home. These have become, amongst the direct utility factors of the forest, perhaps the most important ones.

The capital invested in forestry is represented by the soil and the trees growing upon it, the former being the fixed and the latter the movable or fluctuating capital. If the management of this capital is bad, as is the case when the working is intermittent and unsystematic, the capital is not only subject to fluctuations, but also depreciates, both crop and soil being subject to this depreciation. When, on the other hand, the woods are managed so as to give equal annual returns or periodic returns and are under regular systematic treatment, the capital either remains the same, yielding an even rate of interest, or, with the improvement of poor waste lands, which follows from placing them under a crop of trees, will increase in amount, this increase affecting both the fixed and movable capital.

Lastly, we come to the important question of the utility of the forest in its effect on the employment of labour. The labour which depends upon the existence of areas of commercially managed forests in a country may be divided into three categories.

Firstly, that required for the work connected with the formation of the woods, their subsequent tending and upkeep-for once planted, a wood cannot be left to shift for itself, as has been so commonly the case with us in the past, any more than can an 
agricultural crop-the felling and conversion of the crop, and the general administration of the area. Secondly, the operations connected with the extraction and transport of the produce to the markets. And, thirdly, the labour employed in the various industries which depend upon forest produce for their raw material, industries which always arise in countries maintaining as part of their national economy areas of properly managed commercial forests.

We will now glance at the indirect utility of the forest. This may be briefly summarized as follows :

Considerable areas of forest in a country exert certain influences on the temperature and humidity of the air and soil which in our moist and more or less equable island climate are not of any great outstanding importance, though the case is quite otherwise in many parts of our great Empire. The climate of the British Isles is second to none for the growth of forests, but their maintenance is primarily required for reasons other than climatic. Forests also tend to regulate the flow and supply of water, to maintain an even and permanent output from springs, to maintain the level of rivers, so important in cases where the latter are used for power works, and to prevent or reduce violent floods in the latter. Floods are usually the result of heavy rainstorms falling on bare hill or mountain sides away up on the catchment areas of the rivers. The rapid flow of this water down the bare hill-sides, in addition to causing flooding and silting up in the rivers, also results in serious erosion taking place on the former, 
causing avalanches, which cover up with masses of rock and debris valuable agricultural land down below. Woods are also useful in arresting areas of shifting sand, also destructive to agricultural lands; and in stopping coast erosion.

Good work of this nature has already been undertaken by planting up areas in the Moray Firth in Scotland, on the West Coast of England, and elsewhere in this country. In France we have the fine example of the maritime pine forests on the Landes in Gascony. Large sums of money were spent in the formation of these woods, but they have since proved a gold mine to the French Government, although originally planted for purely protective purposes. And we ourselves have benefited in the past, and are doing so at present, for much pit wood comes from there. Woods also afford shelter, as we have seen, to the crops and stock of the farm, and their utility in this respect is well understood in this country. Their planting and management has left much to be desired in the past however, and many of them could be replaced by well-ordered masses of forest worked on commercial principles and grown on areas at present all but unproductive. Woods also afford shelter to game and useful birds. Another important indirect use of forests is to be found in their hygienic value, a point but little understood or valued in the past in this country. It is an indisputable fact that the air on wooded and mountain sides has certain healthful properties which exert their full influence on the jaded human being worn out with work, high living, and the incessant excitement 
of modern life. Such areas are also the best in which to place sanatoria. It is possible that the medical faculty will turn a greater attention to this point in the future.

The catchment areas of the water supplies of our great cities and towns provide another instance of our ignorance of the utility of woods. Not only do the trees maintain a larger supply of water in the reservoir, a point perhaps of less importance in our climate (though one of the chief in a hot dry climate), but they exert an incalculable influence on the purity of the water. We have been slow, extraordinarily slow, in realizing the great importance of planting up our catchment areas. Manchester was the first to show the way in this respect, but most of the other great cities of the country have not got beyond the "matter is under consideration" stage. Of course many of the towns do not own the land forming the catchment areas of their reservoirs. These may be wholly or partly agricultural land. In this case, year after year manure full of bacteriological death for the human race is dumped down in heaps and subsequently distributed over fields in the immediate vicinity of the reservoir from which the inhabitants of a great town draw the whole of their water supply!

Finally, woods have a beauty all their own, which makes its own appeal to a large proportion of the human race. This aspect of the forest cannot be without some beneficial effects on the population of a country. 
PART I

THE PAST 



\section{I}

FORESTRY IN GREAT BRITAIN IN EARLY TIMES

WHAT do we know about the woods, the old forests, - of our own country, their past history, and the cause of their present absence? We have heard mention of, many of us have seen, the Forest of Dean, the New Forest, Windsor Forest. Londoners know Epping Forest; but how many of them realize that Epping is the remnant of an old Royal forest once embracing the whole of Essex! Dean, New Forest, Windsor, are all remnants of such forests, survivals from the time when the greater part of these islands was covered with a vast forest in which the ancestors of the members of the greatest of present-day Empires walked about clothed, we are told, in blue paint.

This forest history of ours is fascinating, even though it had all but ended when the Great War broke out, and it appears to be well worth rescuing from the obscurity in which it has become enshrouded.

Our ancestors away back in our history knew all about the utility of forests so far as their utility was understood at that day. They utilised the forest to the full for their several purposes: the 
rich and powerful for hunting and the chase; the poor to obtain from it certain necessaries of their existence. And for these ends the forests were maintained, even added to, as will be shown. And in later days, when the forests had come to assume a definite position in the economic life of the European nations, our forefathers were not behind the others. British forestry was as good as anything the Continent could show. It studied the requirements of the people and the nation, and grew the timber crops and coppice crops to supply the market demands of the period. And it grew them in the best possible manner, as those responsible for the upkeep of our old wooden Navy, which depended upon them, were fully aware. It is only during the last century and a half that we gradually lost the forestry art of keeping pace with the times and changes of markets. There were reasons for the decadence of British forestry, as will be indicated, but it has resulted in our present-day almost total ignorance, as a nation, of forestry methods.

Let us trace this history for a little.

We will take it up at the time of the Roman invasion of Britain. We know that in olden days the British Isles were in all probability for the most part covered with a great stretch of primeval forest, the broad-leaved trees, such as the oak, beech, ash, etc., in the plains and low hills, whilst the Scots pine formed the chief species in the mountainous tracts, this latter being our only indigenous conifer. The axe, but more commonly fire, swept away the great forests of the latter, leaving the 
mountains bare and denuded as they exist at the present time, witness the mountains of Wales and the Scottish Highlands.

Three distinct periods are distinguishable in our forest history:

I. From the time of the Romans, A.D. 44 (where I propose to begin), to the passing of the Statute of Enclosure in I482.

2. From the passing of the Statute of Enclosure to the appointment of a Parliamentary Committee on Forestry in I885.

3. From the appointment of the Parliamentary Committee in 1885 to the outbreak of the Great War in IgI4.

I. The History of British Forestry from the Time of the Romans (A.D. 44) to the Passing of the Statute of Enclosure in I482.

A very considerable proportion of these islands was covered with forest at the time of the Roman invasion. The population was still small, only insignificant areas being required for cultivation and the sites of the small towns and villages. The Romans assisted to some extent in decreasing the forest area by driving their great roads through the country and in clearing areas for their encampments, and to prevent ambuscades. But at the end of the Roman occupation (A.D. 4IO) the country was still thickly wooded.

At the time of the arrival of the Romans in Britain the species of trees occurring in the woods consisted 
of the oak, beech, hornbean, ash, birch, Scots or Wych elm, yew, aspen, alder, willow, mountain ash, holly, and hawthorn amongst the broad-leaved trees, with Scots pine the only conifer. The oak forests occupied the deep, rich, alluvial lowlands, whilst the beech formed dense forests on the uplands of southern and central England. The sandy areas in the south of England and the mountainous tracts stretching from Yorkshire to the north of Scotland were probably chiefly covered with Scots pine, birch, and mountain ash, the other broad-leaved species occupying the more sheltered, low-lying localities in the island.

During the Roman occupation many species of trees, forest and fruit and ornamental shrubs, were introduced by them into Britain, some of which flourished whilst others failed. The chief of these introduced trees are the sweet chestnut, English elm, poplar, and lime. These are now widespread, but their seed only rarely ripens sufficiently to have reproductive power. All of them may, however, throw out sucker shoots from their roots. It was only after the lapse of a thousand years from the departure of the Romans that other species of trees were imported into the country. In the fifteenth century the sycamore, white and crack willows, and the white and grey poplars were introduced; the cluster pine and the spruce in the sixteenth century; silver fir, maple, horse chestnut, and larch in the seventeenth century; Weymouth, maritime, Cembran, and pitch pines in the eighteenth century ; and Austrian, yellow, and Jeffrey pines, Nordmann's and Douglas 
firs, Sitka spruce and Japanese larch, etc., in the nineteenth century.

From early times after the departure of the Romans the forests in England were utilised by the King and his nobles for purposes of sport and the chase, and by the peasants for grazing and pannage purposes-i.e. for feeding their large herds of swine on the acorns and beech mast when it covered the forest floor in the autumn. Large tracts of country were reserved as Royal hunting-grounds, these areas consisting of blocks of country which included agricultural land, waste lands, as well as forest. Within the Royal hunting-grounds only the King and his nobles were allowed to hunt, and penalties were enacted to safeguard the animals of the chase-the red deer and so on. But neither the Saxons nor the Danes pressed hard upon the people in the reservations made in this fashion for the chase. It was after the Norman conquest, by which time the forest area, under the persistent attack kept up on it to provide more land for tillage and for the increasing towns, was beginning to show some contraction, that real hardship was suffered by the rural population. William the Conqueror and several of his descendants were passionately fond of the chase of the "tall Red Deer." William I. took over the Royal hunting-domains of his Saxon predecessors. Within a brief interval he became alarmed at the rate the forest lands were being disforested, and to prevent this he extended the boundaries of the hunting-grounds of the Saxon Kings and called them Royal forests, all such lands 
being termed " afforested" lands, and coming under a new, very stringent, and cruel code of forest law which he caused to be enacted.

Manwood, in his Lawes of the Forest, published three centuries ago, thus described these Royal forests :

"A certen Territorie of woody grounds and fruitful Pastures privileged for wild Beasts and Foules of Forest, Chase and Warren to rest and abide there in the save Protection of the King, for his Princely Delight and Pleasure."

The remnants of two of the largest of these newly constituted "Royal forests" are extant in the Forest of Dean (in Gloucester) and the New Forest (in Hampshire). As has been indicated, half a county or a whole county, including the forests, private estates, agricultural land, moors, etc., might be created a Royal forest, and then the whole area came under the forest law. The whole county of Essex formed one of these reserves. The nobles, farmers, and small holders were left in possession of their property, but could commit no act against the forest law, such as hunting a red deer or boar, etc., felling oaks (the oak was a royal tree), and so forth.

In addition to the word "forest," which, as we have seen, owes its origin in this country to Norman times, the words " chase," "park," and "warren " occur. A chase and park indicated some form of forest. The chief difference was in the matter of the ownership of the hunting rights. We have seen 
that the Royal forest belonged to the Crown. In a chase the hunting rights were often vested in a subject usually as a gift for good service. Sometimes a part of a forest was turned into a chase or vice versa when the King seized a chase and converted it into a forest. The forest laws applicable to a forest were not applied in all their severity to a chase.

A park was an enclosure surrounded by a wall, hedge, or fence, and was a privilege given by the King to a subject.

The warren was a right to hunt certain wild animals over specified unenclosed waste lands otherwise free to all, provided such lands were not within the limits of a forest, chase, or park. An inexpensive gift for the King to give to a camp follower or underling was the grant of exclusive hunting over a piece of ground in this manner, the grant consisting of the land plus the right to hunt hares, rabbits, and birds, but not Royal game, on it.

We are coming back to this old idea, which we have long practised in India, and is in force in Russia and elsewhere, in the suggestion of settling soldiers on small holdings as a reward for good service during the war. In fact the Dominions have already started schemes of this nature.

Foresters were appointed within the Royal forest to see that no offences were committed and to apprehend offenders. The penalties were in conformance with the times-e.g. in William I.'s time the penalty for slaying a red deer was having your eyes gouged out, and William Rufus went one better 
by exacting the death penalty. William Rufus extended the "Royal Forests," and this extension was carried on by Henry I., Stephen, and Henry II. It was the extensive new afforestations of the latter King which finally brought the people relief, as he was eventually forced to relax the severity of the forest law. By a statute enacted in II84, and known as the "Assize of Woodstock," the old forest laws were modified and made independent of the common law of the country. Special forest courts were appointed to be held regularly, termed the "Woodmote," meeting every forty days; the "Swainmote," held three times a year; and the "Court of Eyre," or High Court, meeting once in every three years. This was a great improvement, even though gross abuses and bribery quickly crept in. The Magna Charta, I2I5, was the next step in further modifying the forest laws, and in the following reign, that of Henry III. (I2I6-72), large areas were disafforested and many of the forest burdens removed by the King.

In nearly all the Royal forests, the Dean for example, places called The Purlieu are to be found. This word was given to the areas afforested by Henry II. and disafforested or made "pure" by Henry III.

It was during the Regency, whilst Henry III. was a boy, that the famous Forest Charter of I2I7 was obtained by the people, and it was subsequently revised and modified in I225. A clause in this, one of our most famous charters of those times, ran as follows: "No Man from henceforth shall lose 
neither Life nor Members for Killing our Deer." The penalty instead was imprisonment for a year and a day or a fine-a big difference!

Edward I. carried on this policy of disafforesting large areas of the Royal forests and lightening the burdens of the Forest law. Of course, by " disafforesting," as here used, I would not be understood to mean that the forests in theșe areas were cut down. They were far too extensive at that period to have rendered this possible. The disafforesting simply meant that the areas so treated were no longer subject to the forest laws. The policy was continued in subsequent reigns, until with changing conditions of social life the forest law gradually lost its importance, and finally disappeared in the seventeenth century.

One curious result of the high-handed action of the Norman kings for which our generation should be grateful, is that by the end of the eighteenth century the only areas of the old forests of the country left were the remnants of the Royal forests of Dean, Windsor, the New Forest, Epping, etc. For assuredly, but for the fact that these remained Royal forests-i.e. were not " disafforested "- - they would have disappeared with the rest, as will be described.

It is of interest to note that the animals protected in the Royal forests were, firstly, the Royal red deer (the hart and the hind), the fallow deer (which may have been introduced by the Romans), possibly the roe deer, and the wild boar, next only in importance to the red deer. The wolf was present, but probably 
did not form one of the animals of the chase. The fox, badger, otter, and wild cat are also mentioned as preserved animals.

I have said that the forests were under the charge of foresters. There was, in fact, a considerable staff of varying grades and appellations, from nobles downwards. The lower grades had distinguishing badges of rank, and many of these are to be seen on old tombstones in graveyards in the Forest of Dean and elsewhere. For instance, the badge of a verderer was an axe; that of a forester-of-fee, a hunting-sword and horn; that of a chief forester, a bow or an arrow ; of a forester, a hunting-horn ; and so forth. The clerical staff of the forest was represented by the agisters, who collected the grazing and pannage fees from the people.

The one hundred and eighty years succeeding Edward I.'s disafforesting edict witnessed a considerable curtailment of the forest areas of the country since the existing forest law did nothing towards protecting the woods of the disafforested areas. Thus at the end of the period-i.e. in the latter part of the fifteenth century-the forestry question in its economic sense had begun to make its appearance in the country. This forms the history of our second period. 


\section{II}

FORESTRY IN GREAT BRITAIN IN LATER TIMES

THE second period into which I have divided this brief historical review merits our most careful attention at the present juncture. For it presents parallels to our present position in timber supplies and to the question of afforestation.

2. From the passing GF the Statute of ENCLOSURE, I482, to THE APPOINTMENT OF A Parliamentary Commitee IN 1885.

It was during this second period that the science of British forestry had its origin, reached its zenith, and, from various economic causes closely bound up with the history of the trade of these islands, subsequently declined, until by the end of the period it had practically ceased to exist as an economic factor of importance in the life of the people.

Towards the close of the period already described the Government became uneasy at the rapid rate at which the forests of the country were disappearing, and in I482 the "Statute of Enclosure " was enacted. This was only applicable to the Royal forests, chases, and purlieus of the "disafforested" lands (i.e. the 
lands freed by the previous charters from the forest laws) of England. The Statute permitted proprietors owning land therein to fence their coppices against deer and cattle for seven years after each felling. The fear of a shortage of timber continued to exercise the minds of those in power, and the Statute was followed in I543 by a "Statute of Woods." Therein it was enacted that all woods throughout England should be enclosed for four, six, or seven years after each felling of the coppice, according to whether the rotations of the latter were under fourteen, fourteen to twenty-four or over twenty-four years, and that at least twelve standards her acre should be left standing, or "stored" as it was called, to grow into timber size. These standards were to be oak when possible, or, failing oak, ash, beech, elm, or aspen, these being the timbers most in demand after oak. A certain age or girth was laid down for these standards, which were not to be felled before reaching the prescribed age or size. From this far-sighted action dates the first systematic management of British woods, for from it and subsequent Acts of Parliament arose the practice of working the woods on the sylvicultural system known as coppice with standards. The standards, as we have seen, were chiefly oak, beech, ash, elm, and aspen, whilst the coppice or underwood consisted of oak, chestnut, hazel, ash, birch, willow, etc. The working of the woods in this manner gradually spread north throughout Scotland, when the land was suitable, and over into Ireland after the Act of 1634 .

This system of management of the woods was in 
conformity with the requirements of the markets of those days. The small material of the coppice was readily disposed of for the requirements of the people. The standards, which had to grow at a certain distance the one from the other in order to give sufficient light for the development of the coppice beneath them, consequently produced large crowns containing knees and crooks which were in demand for the shipbuilding yards from which emanated the old wooden ships of our Navy and mercantile fleet. The watchful care of the Parliaments of this period, and their enactments to ensure the proper management and protection of the British woods, were solely due to a recognition that the upkeep of the country's fleets was dependent on the maintenance of a sufficient area of British woods managed on the lines most suitable for the production of the national requirements. In fact, the Government realized that the national safety depended on this margin, the national safety margin, being maintained. It was this factor, and this one alone, which kept the question in the forefront for something like two and a half centuries-down to the time in fact when, early in the nineteenth century, having obtained the command of the seas, timber imports began to make their presence felt on the home markets, up to then supplied from home woods. In this long period there were ups and downs of course. A markedly critical period owed its origin to the action of Henry VIII. in seizing upon the Church lands in the year I535. These lands contained fine woods, many of which were 
cut down by the nobles to whom they were granted by the King. However, this action did not affect the country to any serious extent, since the demand for timber materials at that time was more than covered by the available supply.

A far greater devastation of the woods took place during the Civil War. From I642 onwards, up to the Restoration, fellings were carried out on an enormous scale, whole forests being completely razed to the ground, whilst other large areas were laid waste by fire and wanton destruction. So serious was the damage, and so grave the position of the nation with reference to its timber supplies, that within four years after the Restoration the matter was brought to the public notice by the Council of the newly founded Royal Society, who commissioned one of the members, John Evelyn, to deal with the matter in a Memorandum. To this action we owe the Sylva, Evelyn's great classic, in which attention is drawn to the serious position of the timber supplies of the country, and all proprietors from the King downwards are earnestly exhorted to plant trees. There can be little doubt of the danger in which the nation stood owing to the cessation of planting, which was widespread throughout the country - a natural aftermath of the long period of internecine warfare when men had something else to do and think about outside their estates; the retention of which, moreover, depended upon their side being victorious. The stoppage of planting was therefore a perfectly natural outcome of the times the nation had passed through, and a 
thorough awakening to the dangerous situation only too necessary. The action of the Royal Society and their member, Evelyn, aroused the nation, and a large amount of planting was undertaken during the next decade. Even in 1678 , four years after the publication of the Sylva, Evelyn was able to report to the King that millions of trees had been planted. The result of this crusade is even more interesting. A hundred years later, the fact that there was sufficient timber in the country for the construction of the ships of the Royal Navy was publicly acknowledged to be due to the planting indertaken in the reign of Charles II. on the initiative of the Royal Society. It is equally certain that most if not all of the ships which fought the battle of Trafalgar, and which previous to this had secured the Command of thc Seas, were built of timber planted at the revival period dating from the publication of the Sylva.

Curiously enough, or more probably as a direct outcome of the stirring times of the latter part of the eighteenth century and early part of the nineteenth, planting had again fallen into desuetude. There was an attempt at a revival, since at a time when the French were challenging our command of the seas it was as much needed as ever. During this period the newly founded Society of Arts offered premiums and medals to those sowing the greatest areas of land. But from I820 onwards planting of woods as a commercial proposition ceased. And the reasons are easily traceable. After Trafalgar, with the command of the seas assured, 
timber imports began to come into the country on a large scale. The Admiralty had already some time before begun to use teak from the Moulmein forests. Oak was no longer the only stand-by for the Navy. But above all, the steamship made its appearance, and with it a system of more rapid communication. The home forest product, however, still readily found its market, as duties had to be paid on all imported timber. In I846 a step towards free trade in this respect was taken by removing the import duties on Colonial timber. This was followed by an upward leap in imports and a corresponding depression in home timber values. But already the demands of the markets were changing. The old methods of building ships were changed by the use of steel, etc., the building trade were employing cheaper materials, which replaced the fine old English timbers by the long, straight, clean-grown firs and pines of the North European forests. The old furniture industry was following suit. We had arrived at the Mid-Victorian age. The soft woods were capturing the markets. The final death-blow to British forestry was dealt in I866, when the import duty was removed from all foreign timber. This gave the Scandinavian forests their great opportunity. The timber export industry in Sweden had its first beginnings about $185^{\circ}$. It had already assumed fair proportions by 1866 . With the removal of the British duties, Sweden, in the altered conditions of the market, became one of our chief suppliers for many years to come. Norway and, later, Russia began exporting largely 
to the facile British markets, and the imports from America and Canada largely increased. Even distant Australia was able to compete.

It will be asked why, with this large demand for materials in the country, we could not continue to take a hand in its supply, since we were on the spot. The answer is twofold, and I will give the one most flattering to our vanity the precedence. The timber imports which came into this country from early in the nineteenth century up to the outbreak of the war were mostly cut from trees growing in primeval forests situated close to water, so that the carriage was entirely water-borne-the cheapest method of transport; further, these trees had not been grown by man, and therefore had not to bear the costs of such cultivation, and lastly, the price paid for them standing in the forest by the wood merchant was but a small fraction of their value. Thus even had we had the same quality of material, we should have found it difficult in many cases to put it on the market on the same terms as the imported article. But we had not the quality or kinds of timber the changed conditions of the market now demanded. Nor did we attempt to grow them. The history of British forestry after the great changes on the markets is in fact a most pitiable one. The Government, quite rightly so at the time perhaps, grasped the changed conditions, attracted imports, and paid no further attention to British forestry, which, so far as they were concerned, had had its day. But the Crown forests and the woods on private estates still continued to be kept up and managed on the old 
lines. In other words, proprietors were oblivious, for they could scarcely have been ignorant, of the altered market conditions, and woods all over the country continued to be managed in the old way and for the production of the old material-i.e. coppice (for which there was still a demand) and standards (for which the chief demand was gone). The markets no longer wanted the old knees and crooks from the branches of big-crowned trees. Soft woods, pines and firs, were now chiefly in demand. Clean, straight timber of good length was now asked for. This can only be produced by growing the trees densely on the ground and opening them out comparatively slowly. The old heavy thinnings made to furnish each tree with plenty of room, which result in shortheight growth and a large crown, were now useless, as there was no demand for the article they produced.

To some extent before the end of this second period pure woods of conifers had been planted (notably in Scotland-e.g. the great larch woods of the Atholl estates planted by the "Planting Duke" early in the nineteenth century). But in the treatment of these coniferous woods we again went wrong. Instead of applying the rules of thinning for these previously untried species as applied on the Continent, which could have been easily ascertained by the proprietors, the matter was left to the foresters, who carried on the old British rule of heavy thinnings. The foresters knew no better. How should they, scientific forestry training being entirely absent in the country. But the results were disastrous for the owners and ultimately for 
the country. In the great wars of a century and more ago our ancestors were left in a position to carry on with success, since they mainly depended upon the Navy, and the Navy had been provided for. Their descendants in the Governments of the past century, satisfied with the increasing imports and trusting to the changed economic conditions, made no further provision in this matter; nor can they be fairly blamed, since the most vivid imagination could not have pictured the conditions under which the present war was to be fought.

The last two factors in the period under consideration are the termination of the American Civil War in 1867 and the formation of the German Empire in I87I. Each event was followed by a very rapid increase in the population and commerce of these countries, increases which brought them into competition with Great Britain, till then the greatest industrial country in the world. The growth of these countries had its effect on the timber supplies, and by 1885 both of them were annually using enormous amounts of timber. We had to face this competition, and timber prices gradually rose. Experts recognized that the supplies were mainly coming from primeval forests, and that their comparative cheapness was due to the fact that the areas being felled were the accessible ones near the seaboard or on the banks of rivers and streams-that, in fact, the major part of the produce was reaching the markets by water carriage alone. Already by 1885 it was being asked how long this state of affairs could last! 
THE REVIVAL OF FORESTRY IN GREAT BRITAIN

A FAINT stir of unrest, a suspicion that all was not well with the country's position in the matter of forestry, began to make itself felt in the early eighties, and this leads us to the third period into which I have divided this brief historical survey.

3. From the Appointment of the Parliamentary Committee on Forestry in I885 TO THE OUTBREAK OF THE GREAT WAR IN IgI4.

This third period is perhaps the most interesting in our forestry history, for it throws a strong light upon many factors in the pre-war organization of our national life, parliamentary, social, and economic. It also brings into strong relief the depths to which forestry in Britain had sunk, and proves incontestably the ignorance existing in the country on all pertaining to present-day woodcraft, in so far as the object of that craft is to furnish materials of indispensable value to modern industries dependent upon it.

The unrest which came to a head in the middle eighties was met by the Government of that day 
in our time-honoured fashion (for it invariably contented the majority of us in the past, whatever our attitude may be in the future) by the appointment in 1885 of a Parliamentary Committee to consider "Whether by the establishment of a Forest School, or otherwise, our woodlands could be rendered more remunerative."

Now, reflexion will show that there were two parties in the country who had a direct interest in this matter, the Government on the one hand and the proprietors of woods on the other. The interest of the Government in the question can at best be only described as lukewarm. The I885 Parliamentary Committee was, as we shall see, followed by others during the next thirty-five years, but little resulted from the deliberations of these bodies. The Government were satisfied that the country was obtaining all it required in forestry materials by imports, and the Navy still held the command of the seas to safeguard these imports. True, the German bid for sea supremacy was producing serious anxiety towards the end of this period, but the fears thus aroused were not based upon any idea that timber imports were likely to be interfered with. It is doubtful whether the question of an actual interruption of food imports ever crossed the mind of Government or public. The case for the Government is, therefore, understandable, and with the Government we may include the bulk of the public. The other party in the country having a direct interest in forestry matters were the private landowners, who owned between them $97^{\circ} 7$ per cent. 
of Britain's $3,000,000$ odd acres of woodlands, the other 2.3 per cent. being the Crown woods (Forest of Dean, Windsor, etc.).

The attitude of the private proprietors of woodlands during this period is, at first sight, not so easy to explain. Presumably, since they had a portion of their capital sunk in the woods, they should have had a first-hand interest in obtaining the best return possible on this capital. But the reverse was actually the case. The woods were for the most part understocked and managed on wrong lines. The material produced was rough, heavy, knotty, and short in length. Colliery owners did not care to take British fit wood, as the miners refused to use it, preferring the clean-grown material imported in quantities from abroad. British timber was not in much better case. Government specifications for timber required by Government departments especially stipulated that British timber (with the exception of some of our more valuable hard woods) should not be used, owing to its inferior character, due entirely to the methods upon which it had been grown. For we have yet to see timber which can beat British material for quality once it is grown in the proper way. Added to these factors, the woods were managed on very erratic and slipshod methods as regards fellings and replantings, these important operations being carried out in a haphazard fashion, as the will of the owner, estate agent, or forester decreed at the moment. Timber merchants of any standing consequently preferred to confine their chief operations to foreign timber, owing 
to the absence of any continuity in the supply from definite areas of woods in Britain; whilst the railways refused, and the refusal is scarcely surprising, to carry the material at reduced rates, since it could not pay them to make the necessary arrangements required for the transport of such a bulky class of material as timber unless a continuity in the supply from a particular district was forthcoming. And the existing management precluded such continuity.

Now, what was the reason for this state of affairs? It was obviously merely a question of the ordinary laws of supply and demand. We all of us buy the articles we require in the best and cheapest markets we can find, and this tendency was influencing the timber markets. The proprietors of woods were naturally aggrieved at the state of affairs, which to the majority was an enigma, and was so to many when the war broke out. A few had, however, begun to grasp the true position-a very few. For the greater number their estates were worked almost entirely by their agents and factors, the management of the woods being either in the latter's hands or, in the case of estates having considerable areas of woods, more directly in the hands of the foresters. The owner for the most part neither knew, nor pretended to know, anything about forestry. $\mathrm{He}$ liked his woods to look at and to shoot in. In the hard times of agricultural depression, which were hitting him so severely, he may at times have wished wistfully that his woods could be made to bring him in a stable income on which he could depend; 
but the majority ridiculed the idea of such being within the bounds of possibility. The bad gales experienced in this country were against it for one thing they would tell you, and quote so and so who had lost hundreds, may be thousands, of acres blown out. But they were unaware that indifferent planting, the haphazard felling methods by which an old wood was felled, thereby exposing to the full fury of the next gale a series of younger ones which had grown up in its shelter, and the absence of all attempts to plant shelter belts were to a great extent responsible for the devastation done in British woods by gales.

The estate agent was usually equally ignorant of all pertaining to forestry matters. The demands of the gamekeeper on the estate, with reference to the management of the woods, were far more important in his eyes than those of the forester, and were almost invariably given precedence, to the detriment of the woods. And for the forester, you will ask where he came in! Well, he didn't come in. According to old methods he knew his work well. His nursery and his planting work, in spite of his persistent love for the British method of notch planting with the ordinary spade, probably one of the most pernicious ever invented, were good; his nursery work in Scotland probably the finest in the world. But after that he could only do as his forefathers had done before him, for he had nothing else to go by.

How could this state of affairs have persisted in the country for so long? How could the capital 
invested in 3,000,000 acres of land have been allowed to depreciate to the extent it did depreciate year after year without its owners making an effort in its favour? The reason, I think, may be attributed to two causes. The first, the absence of forest education. A specialised education it is true, education in the principles of scientific forest management. Why did not this truth present itself with overwhelming force to the landowners? It did not do so; had not done so, not to proprietors as a body, when the war broke out. It may have been due to the firm belief held by the average landowner that his woods could by no possibility be made to pay. His agent told him so; his gamekeeper looked upon them, and treated them, as a mere adjunct, a necessary adjunct, to his job; and the forester, with the market obviously supporting the agent and gamekeeper, the market which would not take his produce, could only curse the foreign materials and yearn for the old days back again. For the forester, no more than his proprietor, understood the real reason for the position he was up against; nor was the remedy at any time in the hands of the former. The second cause which militated against the woods being treated and worked as a commercial proposition was the fact that, with certain exceptions, they were chiefly regarded from their usefulness in affording sport or amenity. When viewed from this aspect, the owner may be considered to have got some return before the war on the capital invested.

To return to the position in the eighties, if the 
analysis already given is correct, and a careful study of the whole field would seem to indicate that it is, the instructions to the Parliamentary Committee to consider "Whether by the establishment of a Forest School or otherwise our woodlands could be rendered more remunerative" is understandable. The appointment of this Committee was doubtless secured by a few members of the House of Commons acting in co-operation with others of sufficient influence outside it. The few had put their finger on one of the causes of the position of British forestry at the time. The Report issued by this Committee does not indicate, however, that its members had realized either the position or their great opportunity. They agreed that the conditions of the woodlands of the country might be materially improved. They expressed a hope that the waste of forests elsewhere in the world would eventually give British woods a chance. They recommended the establishment of a Forest Board, though the absence of fully qualified trained men to sit upon it was well known, and they considered that the " establishment of Forest Schools, or at any rate of a course of instruction and examination in forestry, would be desirable," the details to be left to the Forest Board. "The expense of the secretarial staff and examiners need not in the opinion of the Committee exceed $£ 500$ a year."

It was scarcely to be expected that matters could advance very rapidly at this low cost. Nor did they. Planting was also advocated, although the evidence as to whether forestry in Britain would pay 
was conflicting, as well it might be under the conditions existing. No planting was undertaken.

Then came a second Committee appointed in I889 " to inquire into the Administration of the Department of the Woods and Forests and Land Revenues of the Crown," the report being published the following year. This report was somewhat misleading. Its main statement was to the effect that "the Committee are of opinion that on the whole the estates are carefully administered." An hour's walk through several parts of the Forest of Dean will disclose the most glaring mistakes made about that period and in earlier years against the most elementary sylvicultural canons. But in the absence of scientific forestry knowledge in the country, how could it be otherwise?

Before passing to the next Committee, one scientific training centre for forestry existing in the country at this time, that of Cooper's Hill, may be alluded to. But such is our extraordinary method of doing things, this centre placed close to Windsor Forest exerted practically no effect on British Forestry as a teaching centre during the whole course of its existence, because it was an Indian College, maintained by the India Office. Cooper's Hill was an Engineering College designed to train men for the Public Works and Telegraph Departments in India. Forestry was tacked on in I885 to make the place pay, for it was a very costly establishment to keep up. For the forestry student it was an ideal centre (and having been trained there myself, I speak from personal knowledge), with its easy access and 
woodland surroundings, and it would have made a magnificent centre as a British and Empire Forestry School.

But although as a Forestry Training Centre, properly equipped as it was with teachers capable of imparting a sound knowledge of scientific forestry, it had no effect in affording this training to British foresters (owing to the considerable fees payable by students), it would be unfair to assume that Cooper's Hill, through its professors, had no effect on British forestry during the period here under review. Professor Sir William Schlich and his assistant, the late Professor W. R. Fisher, were untiring in their efforts in the cause of British forestry. Nor were their efforts without some meed of success - for they obtained the ear of the Government (even if that car only led to more Committees and Commissions that was no fault of theirs) and the ear of some of the more advanced a mongst the proprietors. What man could do, Sir William Schlich has done--spent almost half a lifetime in doing. Not his the blame that the war found us with so little progress made. But was not the foundation laid? Time will show, but I hope to be able to indicate in subsequent pages that it was.

To come back to our Committees. In I902-03 a Departmental Committee of the Board of Agriculture, commissioned for the purpose, issued a report-the third in eight years. This Committee did not take up any afforestation schemes, but devoted itself to a consideration of education in forestry and made most valuable recommendations on the subject, which had as a result the appoint- 
ment of lecturers in Forestry at collegiate centres, such as Bangor, Newcastle, Glasgow, and Aberdeen. A lecturer in Forestry had been appointed at Edinburgh University in I889, the first University appointment of its kind. This was a strong move in the right direction. Another good departure was the creation in I904 by the Commissioners of Woods and Forests of a School for Forest Apprentices in the Forest of Dean, and in 1905 of a similar School in Ireland at Avondale in County Wicklow.

In Igo8 the Department of Agriculture in Ireland appointed a Committee to consider the question of afforestation in that country. It recommended a fairly extensive scheme for the planting of 700,000 acres, and purchases of land for the purpose were subsequently commenced.

In I906 a bigger effort was made-a Royal Commission this time-the Royal Commission on Coast Erosion and Afforestation coming into being. The report, based on a mass of evidence and the examination of a host of witnesses, appeared in I909. The unemployment scare was on at the time, and unfortunately the recommendations of this Commission became involved, and wrongly involved as we now know, with the question of making use of the unemployed in planting work. It was held that the unemployed townsmen would not be able to learn to use a spade nor stand the exposure. We are wiser now, since so many thousands of them have quickly learnt to use entrenching tools and have stood in a marvellous manner the far greater exposure of the trenches in France in the winter. It 
was, after all, only a question of education-training, if you prefer the word. The recommendations of the Commissioners on the score of afforestation erred if anything on the big side. They advocated the planting of 9,000,000 acres by Government, of which 6,000,000 were to be in Scotland, and the balance in England, Wales, and Ireland. Nothing came of it. Not a single tree was planted.

Before I come to the Development Commission (IgI0) I will finish with the Committees of this period. The sixth Departmental Committee (on Forestry in Scotland this time) was appointed in IgII and issued its report in IgI2. It made recommendations on forestry education, and advocated the acquisition of a Demonstration Forest Area. It also considered the question of afforestation in Scotland, and suggested the undertaking of flying surveys of the country to ascertain the available planting areas, the establishment of a limited number of State trial forests, and the appointment of Forestry Advisers. The last recommendation was given effect to. No planting was done. In IgI2 also appeared a Forestry Report issued by the Royal Scottish Arboricultural Society entitled $A$ Forest Survey of Glen Mor and a Consideration of Certain Problems arising therefrom. This report, drawn up by Lord Lovat and Colonel Stirling of Keir, was an attempt to grapple with some of the economic difficulties which confront afforestation in that part of Great Britain. Its pre-war value has unfortunately been discounted to some extent by the vast economic changes which the war must 
necessarily bring about. But allusion may be made to references to a system of leasing areas for afforestation and proceeds-sharing as valuable lines of a probable future departure.

The outcome of the above analysis of the six committees and commissions appointed between I888 and IgI2 to consider the forestry problem resolves itself, if we omit Ireland, in to some small encouragement of education, but a total absence of all planting up of the waste lands of the country.

As an example of one direction in which useful planting work has been undertaken, the reclamation movement of the Midland Reafforesting Association in Staffordshire and Worcestershire may be mentioned. Starting in I904, the Association has already proved the feasibility of afforesting the shale heaps of the Black Country. It is estimated that in the Black Country alone there are some 30,000 acres of land used for piling rubbish upon. Northumberland can also show some good work of this nature.

But the Government had gradually awakened to the economic needs of the country, and to the fact that the services of science and its experts had become necessary to the various industries of the nation if we were to keep pace with other nations and prevent them wresting our position from us. Germany had reached that goal several decades before, and our supremacy was being seriously challenged in many directions. This realization on the part of the Government was reflected in the passing of the Development Commission Act in 
I909, the Commissioners being appointed in the following year. The improvement of agriculture, forestry, house building, harbours, fisheries, and so on were to be questions for the consideration of the Commissioners, and funds were placed at their disposal to enable them to give effect to their recommendations. This Commission was not one of the ordinary kind-i.e. appointed to amass evidence, write a report, and then dissolve. The Development Commission had come to stay.

Inasmuch as forestry was one of the subjects placed in the forefront of its programme, the subject at length received official recognition.

The part of the Development Act affecting Forestry is as follows :

"An Act to promote the Economic Development of the United Kingdom and the Improvement of Roads therein.

Part I. Development. I. (I) The Treasury may, upon the recommendation of the Development Commissioners appointed under this Act, make advances to a Government Department, or through a Government Department to a public authority, university, college, school, or institution, or an association of persons or company not trading for profit, either by way of grant or by way of loan, or partly in one way and partly in the other, and upon such terms and subject to such conditions as they may think fit, for any of the following purposes :

"(b) Forestry (including ( $\mathrm{I}$ ) the conducting of inquiries, experiments, and research for the purpose of promoting forestry and the teaching of methods 
of afforestation; (2) the purchase and planting of land found after enquiry suitable for afforestation)."

Among their other investigations the Commissioners turned their attention to the forestry problem, and it is beyond dispute that they took up the question in a spirit of enthusiasm and approached it from the proper view-point, as the following brief résumé of what was accomplished in the brief interval of four years allotted to them before the war burst upon us will I think sufficiently indicate. Forestry education, advisory work by qualified experts, and the training of qualified experts were placed in the forefront of the Commissioners' policy alike in agriculture and forestry. They put their finger direct upon the open sore in both industries, for without the trained men advance in either direction was impossible. Omitting Ireland, to which I will return, England, Scotland, and Wales were split up into natural groups of counties, and a forestry adviser appointed to each under the Boards of Agriculture, the salaries of these officers being defrayed from a grant from the Development Fund. These officers were attached to either the University or Agricultural College existing in their centre. Private proprietors could obtain advice from the advisers on planting up areas of their land or on the management of their woods. This action on the part of the Commissioners was one of the most progressive achievements for the advance of British forestry yet made in Britain. Funds were also allocated with the object of initiating economic 
research work in forestry. Grants were also made in order to improve or increase the accommodation existing at the various universities and colleges for forestry tuition and research, both of which were, generally speaking, the most inadequate in Europe before this aid was given, and precluded all idea of an advance on the correct lines. The salaries of additional lecturers at several centres were also defrayed.

The matter of acquiring Demonstration Forest Areas in the country, to be utilised as advanced training and research centres, and to afford object lessons in the practical illustration of scientific economic forestry in all its branches, was also dealt with. In England the Crown gave permission for the Forest of Dean to be utilised for this purpose, and the Commissioners provided the funds for building a Research Institute Building within the Forest. The erection of this building had been commenced before, and was completed during the war.

Owing to difficulties experienced in settling upon a site, a Demonstration Area in Scotland had not been acquired by I9I4.

The Commissioners also gave small grants for the provision of small forest gardens to be established near the university or collegiate centres for instruction in the more elementary portions of practical forestry and in which experiments could be made with crops of different species of trees.

Having thus made a commencement in clearing away the most glaring anomalies and deficiencies in the situation, the Commissioners turned their 
attention to the afforestation problem-the afforestation problem which, in spite of the deliberations of six committees, had not yet reached the point of planting one tree of the many millions this country should raise. There was little doubt that at this time the problem bristled with difficulties, a number of which the war has since swept away. The solution offered by the Commissioners was briefly as follows: We have seen that the land belonged to private proprietors, either individuals, corporations, water trusts, and so forth. To such individuals and bodies the Commissioners offered to provide money for the afforestation of suitable areas on the understanding that the land should be reserved for forestry on commercial principles for at least one complete rotation. No rent would be paid for the land, but the owner would receive a fair share of the proceeds from the timber grown on the area. The money for planting the land up to a maximum grant of $£ 5$ per acre to be advanced by the Commissioners, the landlord's share of the ultimate proceeds being based on the proportion which the value of the land bore to the estimated capital expenditure required to produce the crop, this being a matter for negotiation between the indvidual proprietor and the Commissioners before the work commenced. It would be based on the present rental value of the land, its character and other circumstances affecting the finance of the scheme. Owing to the necessarily great variation in these data, it was not considered possible to draw up any general terms of assistance, but stipulations 
were made that the land to be planted should be in a sufficiently large block (not less than 500 acres) to be commercially exploitable with success, and that the woods should be managed on correct lines and be subject to regular inspection by the Forestry Adviser of the District.

This offer did not find approval in general with the few private proprietors who gave it consideration before the war, and this disapproval was perhaps most openly expressed in Scotland. Their chiet objection was over the question of the non-payment of rent for the partial occupancy of the land by the Commissioners. This and other points were still under consideration at the outbreak of war, and therefore do not call for further mention here.

Some of the large corporations of the country accepted the offer of the Development Commissioners, and planting on these lines had been commenced by Liverpool on their catchment area at Lake Vyrmey in North Wales, by Edinburgh on the Talla Catchment area, and by Lanarkshire County Council on the Camps catchment area of 5,000 acres. Birmingham and Leeds also had the matter under consideration before the war broke out. Manchester had been steadily planting up her fine catchment area at Thirlmere for many years past, thus giving a magnificent lead in the matter, and required at the time no aid from the Commissioners.

In Ireland, with the advent of the Development Commissioners on the scene, forestry may be considered to have progressed with extraordinary rapidity. The land conditions were of course 
entirely different, and it was possible to inaugurate a State Forest Department in the Island. Considerable purchases of land had been made by August I9I4, and three large centres were owned by the State, and were being planted up with funds provided by the Development Commissioners on well-drawn-up and carefully scrutinised schemes. These areas are in Central Wicklow, County Cork (Ballyhoura), and at Slieve Bloom in Queen's County.

In this brief analysis an endeavour has been made to present to the reader an impartial account of the result of the four years' work on the forestry problem by the Development Commissioners. The comparison between these four years and the preceding twenty-five may be left to his judgment.

This brings us to the end of our brief survey of nineteen centuries of British forestry, and I will shortly summarize the position as it appears to have stood at the outbreak of war in I9I4.

We have seen that the Government were satisfied with the position in which the country stood so far as timber supplies necessary for its industries were concerned. They consisted of imports it is true, but they were ample, and though these imports were increasing annually (witness the rise by $£ \mathrm{I} 3,000,000$ between I909 and I9I3), and the price of timber itself was nearing an inevitable increase, no anxiety on that score had yet made itself felt. So far as the existing condition of the markets were concerned Government was content.

On the other side of the question they were dubious about afforestation in Britain and its 
prospects as a commercial business. And who can be surprised at their doubts? There were $3,000,000$ acres of woods in the country, representing a considerable amount of capital. Yet in no instance, so far as they were aware, could these woods be shown to be a commercially profitable investment. They were not being managed on a commercial basis, and their owners for the most part were pessimistic or openly incredulous on the proposition that forestry could pay in Britain. Properly kept forest accounts were non-existent. There were no records, no trustworthy records, available. The Crown forests were, up to quite recently, in the same case as the rest of the areas in the country. And the few proprietors who took a real interest in the matter, openly admitted that something was radically wrong with British forestry. Latterly they were of opinion that it was education that was required. In this they were perfectly correct, and in this direction a much-belated start had been made. But the proprietors as a body had no solution to offer as regards the prospects of forestry itself and no faith in its commercial possibilities. The majority were not prepared to sink capital in it themselves, although some of them were of opinion that there might be a case for public funds being utilised for the purpose. This being the position, perhaps it is not to be wondered at that the Government moved very cautiously in a matter in which those who actually owned the woods and the derelict waste lands of Britain were not prepared, from one cause or another, to take action themselves. 


\section{PART II}

THE WAR PERIOD 



\section{IV}

\section{TIMBER SUPPLIES DURING THE WAR}

THE outbreak of war in Europe brought us face to face with our dependent position as regards timber supplies. The greater part of the pit wood used by the collieries was imported, chiefly from Russia, Scandinavia, and France. The Russian supplies ceased with the closure of the Baltic, and those from France with the calling of the woodcutters to the Colours. From the very first, therefore, it was realized that the maintenance of adequate supplies of timber in this country for military and naval purposes-i.e. to enable us to carry on the war--would become a matter of difficulty. But the country was very far from realizing in those days how anxious a problem the timber one was to become. Imports from Scandinavia and America, Canada and Newfoundland, were maintained for the first two years. With the submarine campaign and the increasing demands made on tonnage, these imports gradually dwindled, until they became practically negligible.

From this period we were driven to depend on our home-grown timber, supplemented with such forests as France could place at our disposal. That our ally should have been able to assist us at this 


\section{TIMBER SUPPLIES DURING THE WAR}

juncture is perhaps the best commentary on the value of an organized forestry system to a nation.

In this country Government control had to be instituted over the supplies of timber. The State requisitioned what it required from where it could find it. The private individual could no longer make use of or sell, save as directed, his own timber standing in his own woods, nor could any person buy timber without permission in the market. An open market ceased to exist.

The position being as it was, the restrictions introduced were no more than were essential to the carrying on of the war. And it may be said that they were loyally adhered to by all affectedthe proprietors of woods, the timber merchants, who were naturally greatly affected by these restrictions, and those industries dependent on timber who could no longer obtain the raw product essential to them.

Various and rather ineffectual attempts were made to put the timber supply on a working basis during the first two years of the war. With the increasing demands of the War Office and Admiralty, and the decreasing supplies forthcoming, they failed to produce the desired result. In I9I5, when our ultimate main dependence on home woods was becoming evident, a Home-Grown Timber Committee was appointed to deal with the situation. Later matters were placed on a better basis by the formation of the Timber Supplies Department of the Board of Trade.

This new departure met with unqualified success, and carried out its arduous work with great judgment 
and avoidance of friction, and received the greatest amount of assistance and support from all concerned.

The position of the country in this timber matter was admirably disclosed by Mr. (now Sir James) Ball, the Timber Controller, in a lucid address before a meeting of landowners and agents on December I0, I9I7. This summary of "Timber Supplies During the War" will become historical. I reproduce portions of it below :-

" He would like to give them a short résume of the circumstances which had brought us to our present position, so that perhaps we could better understand the necessities for the full exploitation of the timber in this country, in Ireland, and in Scotland. They all remembered the outbreak of war in August, IgI4, and the enormous demands which were then made on the imported timber supplies, more especially for the Army requirements. That led to a member of the timber trade being appointed Government buyer of imported soft woods; he was appointed by the Office of Works. In I9I5, owing to the advance of submarine warfare, it was decided that steps should be taken to increase the user of home-grown timber, and to that end the Home-Grown Timber Committee was formed, under the auspices of the Board of Agriculture. Numerous sawmills were put up in various parts of the country, principally of the Scotch type, and various woods were acquired, and large orders were also placed with timber merchants and others who at that time were capable of supplying the timber; and supplies so obtained were dispatched to France to meet the ever-increasing demands of 
the British Army at the Front. We had dispatched to the troops at the Front an enormous quantity of English-grown timber. By reason of the enormous demands made on shipping for the transport of the necessary materials required for munitions and other purposes, the available tonnage which we had to bring in imported timber was necessarily curtailed, and as a result further steps were taken by the formation under the War Office control of a Directorate of Timber Supplies-that was in February I9I7-the intents and purposes of the Director being more particularly to utilise our own island resources of timber. At the end of May this Directorate was taken over by the Board of Trade, and the present Timber Control instituted. It might interest them to know what the Department had been doing. He had had the figures taken out, and he found that the Timber Department, as constituted since The Home-Grown Timber Committee came into being, had purchased something like $75,000,000$ cubic feet of timber of all kinds. Some of it they had handed over to various Colliery Associations, and, as they knew, collieries were now under Government control, and they were trying to help them to get wood to carry on their work in the mines; and other timber they had handed over to merchants who had been in the vicinity when the Department had been able to offer it. He would emphasise the valuable assistance and co-operation of the owners of these standing woods. Not only did they give facilities for acquiring them, but in many cases they had been good enough to place at the disposal of the Department their own sawmills and also lend the assistance of their expert foresters. That side of the question was, in his judgment, a rather important 
one, because prior to the war, perhaps, in England, forestry was more or less neglected, it was not the business which we had to-day. In Scotland there had been for very many years a fair demand for home-grown timber, but this did not obtain to the same extent in England, and the assistance which they had had from foresters of the various landowners, who had so readily come to their help, had been of great use to the Department.

"Now, there was another point, and that was what they had paid for the timber. The price had been taken out up to the end of October Igr7, and the figures given to him by the accountant, representing the quantity of timber which he previously mentioned, showed that the average cost to the Department was just over $9 \frac{1}{2} \mathrm{~d}$. per cubic foot. That included hard woods as well as soft woods, but, of course, the major portion of the purchase had been in soft woods. Owing to the larger demand which had been made for homegrown timber and the restriction of imports, there arose a large amount of speculation in home-grown timber and the purchasing of the timber in the woods, and after consulting his various Advisory Committees-of which, as the meeting probably knew, they had a good many-it was decided to scrutinise the purchase of standing timber over $£ 300$ in value, and the Order of July 4 was issued to that effect. Briefly the Order was this : that anybody purchasing standing timber beyond a total value of $f 300$ in three months had to apply to the Department for a permit, and that permit was scrutinised, and provided that the purchaser had the means of working-reasonable means of working within a reasonable time - such permits were freely granted. He might tell them that since the Order 


\section{TIMBER SUPPLIES DURING THF WAR}

came into operation on July 4 they had issued $85^{\circ}$ permits, they had declined four, and the permits under consideration at the moment numbered roo. The quantities dealt with in those permits represented a total of $27,000,000$ cubic feet of timber. Of the 27,000,000 cubic feet he had stated, about $20,000,000$ represented woods which had been acquired for mining purposes-that was, pit wood and pit props. The remaining quantity dealt with sawn timber, and a certain percentage of hard woods, such as oak and ash, were included. The requirements of the country for the coal industry were enormous, based upon the production of $250,000,000$ tons per annum. It was estimated that we required $3 \frac{1}{2}, 000,000$ tons of pit props and pit wood to enable that coal to be got. In other words, for every ton of wood, between seventy to eighty tons of coal were produced, so they would realise the importance of the pit wood industry to enable us to get the coal which was required to carry on.

"In regard to the output of sawn timber, he was hoping that during the next year we should be able to produce some 600,000 standards of sawn timber. That, he need not tell them, must be a great increase on the rate of progress to-day. The present production-so far as one could size it up from figures which had been supplied to them from various sources, and from their own production-was roughly about one thousand standards per day. Under the present conditions they were endeavouring to double that output next year (I9I8), and it had got to be done somehow or other. The timber that was necessary to meet our obligations for next year had to be found very largely in this country, and it was going to tax the efforts 
not only of the whole of the trade, but also the assistance which the Timber Department would be able to render to the trade by means of our Canadian Forestry Corps, the New England Forestry Corps, and also those Americans who came over and brought with them their units, their complete units of sawmill machinery, with the horses and other paraphernalia down to the last button, which they had provided at their own cost, and who were now working in the North of Scotland. In addition, there were our own efforts at the mills which we had working in various parts of the country, but it was going to take us all our time to get the necessary timber to enable us to meet the demand.

"The imports of timber showed there had been an immense saving of tonnage. We had been able to carry on during I9I 7 with much less than was brought to this country in I9I3. That was due to the fact that at last we were beginning to find out that our own island-grown timber, the full value of which was never realised prior to the war, was now giving us that assistance without which we should have to draw very largely upon our available tonnage, which was wanted for other purposes which must of necessity claim priority over timber. Thanks to the timber in this country-which had been planted in many cases perhaps from sporting instincts, also to improve the amenities of the place, but very largely without a shadow or idea as to the commercial side of the story-we were enabled to carry on and so save the tonnage which was wanted for something else.

"All this demand for home-grown timber had brought about keen competition, and that keen competition had resulted in big prices being asked for standing timber. The woods had changed 


\section{TIMBER SUPPLIES DURING THE WAR}

hands several times, with a resulting addition to the price all the time, and the result had been that in converting that timber, having regard to the price which was paid for it, the costs had been on the high side, and in order to prevent the inflation of prices, after a great deal of examination and trepidation, he (the Controller) came to the conclusion, after the fullest discussion with their advisory committees on both sides - the Landowners' Forestry Advisory Committee and the Home-Grown Timber Trade Advisory Committee-he came to the conclusion it was desirable in the joint interests to endeavour to fix maximum prices. He was bound to tell them that he had hesitated a long time before trying to do it, because he had to consider a good many sides of the question, not the least amongst which was production. The Landowners' Forestry Committee gave a good deal of thought to it; the prices were discussed from, he thought, all points of the compass. Some of them were of opinion that the prices suggested were too low, others thought that from the broad national standpoint they had better be accepted. When he came to the traders-the home-grown timber merchantsthey had another side of the story, and they thought that the prices suggested were too high. So, altogether, it had been an exceedingly difficult task to endeavour to bring it to any right sort of conclusion, even after listening carefully to the advice tendered to him by his Forestry Advisory Committees-and he would like to say that they had been of wonderful assistance and benefit to him. He did not claim to be a forestry expert, as they knew; he was merely an ordinary railway engineer with commercial knowledge and intelligence, but the assistance which he had derived from the Land- 
owners' Advisory Committee, the ready assistance which they were ever willing to give him, and also the assistance he had received from the Trade Advisory Committee he much appreciated. The result was the issue of the schedule of December 4, I9I7, fixing maximum prices.... As he had said, he had done the best he could in the circumstances, and he thought-at least he hoped they would think that he had endeavoured to meet the case as fairly as possible.

"There was another point which he would venture perhaps to address to that assembly as representing the owners of timber, and that was this-before the war, in England at any rate, the demand for homegrown timber was small ; in Scotland it was larger; in Ireland it was small also. What was the position now? They were being asked to hand over their woods by the million cubic feet, they were getting in some cases much larger percentages on the cost of the timber than those which obtained prior to the war, not that he thought the prices which, in some instances, were paid for timber prior to the war represented its value, because he had had timber given to him as an engineer for the cost of hauling in the days prior to the war. That did not represent anything to his mind at all, but there had been, and there was still, a large amount of money being paid for standing timber in this country which, had it not been for the circumstances of the war, would probably never have been realised. In that sense they had to take that into consideration when fixing prices for standing timber. There was another point which he would just touch on. As they knew, prior to the war the sale of English timber-of the soft woods in particular-was limited, whereas imported timber was brought to us by our ships 


\section{TIMBER SUPPIIES DURING THE WAR}

from Scandina via, Sweden, America, and elsewhere, and prices ranged from a shilling per cubic foot upwards for converted scantlings. That, to his mind, would have some influence or some effect, and would have to be considered from a purely commercial standpoint in regard to any afforestation schemes which might be set on foot. He should be very sorry indeed if we came to the conclusion that in this country we could not produce soft timber converted from our own island-grown woods - to enable it to share in the trade which he thought ought to come and remain permanently with this country if this timber question were handled the right way. They had issued another Order in regard to Ireland, and that was to control the export to Great Britain of native-grown Irish timber. $\mathrm{He}$ had had strong complaints from members in Ireland that Englishmen had been over to Ireland and exploited Irish woods at the expense of the Irish home demands. It was well known, he thought, that Ireland was not so well favoured with timber in the shape of forests and so on as Great Britain, and owing to the drastic reductions in imported timber, it had been put to him in the form of a resolution that some steps should be taken to prohibit the export of timber from Ireland without some form of inspection and control. He had endeavoured to meet that with the Order which had recently been issued by the Board of Trade.

"There was another question. They had seen the published Orders in regard to timber standing, timber in the round, and converted timber, both hard woods and soft. There was the ever-enormous demand for pit wood they had to deal with. As he had told them, next year we had to get in this country some $3,500,000$ tons of pit wood, and he 
thought there was no doubt we should get it, although he knew the difficulties and what they were. But we should have to get that quantity next year, and the Coal Controller was naturally interested in what prices he had to pay for the supplies of wood to enable him to get his coal. As the collieries were now controlled, it was the Coal Controller who was to be responsible for the expenditure, and the Coal Controller was about to issue, or had issued to the collieries a schedule which had been produced after very considerable consultation with all concerned, that was, with the Scotch authorities, with various English merchants, and collieries and colliery owners, and so forth, and under those regulations collieries would not purchase the supply which they required to carry on at a price beyond a certain figure. That was the position in regard to pit props and pit wood. He hoped we should be able to get all our supplies. We were drawing fieely from Ireland, Scotland, and various parts of England. The collieries themselves, as they knew, had formed Associations. The Coal Controller had divided the country into certain divisions, not only with the view of allocating portions of the timber within those areas for the specific uses of the collieries concerned, but also to regulate and prevent wastage of traction on the railways, which at the present time was one of our difficulties.

"Road damage was another point which affected all of them in dealing with homc-grown timber. It was a question which he had had constantly under consideration since he became Controller. He had made many suggestions, but so far he had not got any tangible results. At the present time, however, the matter was under very special con- 
sideration by all the authorities concerned. It was a very difficult question. People hauling timber were liable to be called upon by various authorities under the Highway Acts in the shape of claims, and he might tell them that, so far as the Timber Control was concerned, they had been shot at perhaps more than anybody else. The public roads in this country, like the railways, had been suffering by reason of the curtailment of the usual repairs. In some cases he was informed that the usual rates which obtained prior to the war for the annual renovation of these roads had not been made, while in other cases some of the authorities, he thought, had laid aside certain amounts, so that the repairs could be dealt with as and when they arose.

But it was not only the timber side of the story which affected the roads. There was the other, and, in his judgment, the equal wear and tear brought upon our roads by the enormous haulage which took place for the Ministry of Munitions, the Air Board, the War Office, and so on, so that to search out and adjust reasonable damage on a claim for damage to any particular party was a pretty difficult job. He thought-and it had been his view for a long time-that we ought to come to a much more simple conclusion on the whole matter. He looked upon this question of road damage perhaps more as one of the necessary consequences arising out of the circumstances of the war, and as such, in his judgment, it required to be specially dealt with. He did not see there was much benefit in wasting our money in litigation as to what should be paid. While he could not tell them anything definite, he might mention that the matter was receiving not only the attention 
of the Timber Control, but also the attention of the Road Board, and representations had been made to the Local Government Board, and he hoped, after due deliberation, they would be able to alter the present machinery and arrive at some reasonable method of dealing with the question, either by accepting the damage as part of the war results or by a slight tonnage charge, so that every one would know what their liability was. At the present time he knew that owners had got their difficulties in getting timber hauled, and so had he. $\mathrm{He}$ knew he could not make contracts as well and as favourably as he ought to do because contractors were not aware what their liabilities were, and consequently sometimes they refused to tender altogether, or they would only come on day work, with any question of damage eliminated altogether. Sometimes they said, 'Well, we will have nothing whatever to do with it,' and so it handicapped the production of the timber which to-day was so essential to meet the country's requirements.

"The present position, then, in relation to timber supplies was that we wanted to double our output in 19I8. The whole timber resources of this country were wanted, soft wood and hard wood; at the present time for all they could produce and put into the market there was an ample demand. In particular, they now wanted ash in order to meet the requirements of the Government for aeroplanes. Landowners had been asked to follow the example of our forefathers, who gave yew to make bows, and give us their ash at a certain price. The appeal was bearing fruit, and they were being offered standing ash at $4 s .6 d$. per foot cube for the selected butt. Thousands of trees had been offered, and his inspectors were now scouring the country 


\section{TIMBER SUPPLIES DURING THE WAR}

examining them. As the ash used must possess certain qualifications, many of the trees offered have not proved suitable, but, nevertheless, the Department much appreciated the assistance offered. There was also a demand for oak as a necessary material required for wagon-building, etc., and in fact a demand existed for all timber, especially soft woods, no matter what it was. There was a ready market for it, so they need have no fear in cutting anything in the shape of timber to-day and not getting a good market for it. ... The great problem which faced the Timber Controller was to get the timber. If the landowners could assist by felling, and by the use of their horses and carts get the timber to the roadside, where it could be picked up by mechanical transport, it would greatly assist. To repeat, they wanted to turn out next year (IgI8) 3,500,000 tons of pit wood, and, roundly, 2,000,000 tons of sawn wood. That was 5,500,000 tons. He thought that we could carry through with that. But $6,000,000$ would be better. That was the present position."

The Controller obtained the supplies he wanted in 1918.

What has been the result of these operations in the country?

We have witnessed the setting up of mills all over the countryside, run by Canadians, Portuguese, German prisoners, and others. Felling has been carried out on an enormous scale, especially in the coniferous woods, the pine, larch, and spruce, throughout the country. The lumbering methods of the New World were introduced into our small woods.

To the casual observer before the war, England 
and Scotland must have appeared to be well wooded. England, with her numerous hedgerow trees and clumps and patches of woodland of varying size; Scotland, with an absence of hedgerow trees, but larger areas of woods, especially conifers.

As we have seen, there were some three million acres of woods in the country, but they were poor in quality owing to the inferior methods upon which, for the most part, they had been grown. They were very much scattered, often having been planted with no reference to the possibility of being able to extract the material when it had matured owing to the absence of efficient transport lines. This timber, in the majority of cases, had been produced at an extravagant cost; it had scarcely a market before the outbreak of war. Being restricted to our home supplies we had to make use of the existing material, with the consequent lowering of the market quality of the material used and an enhancement of the price due to the shortness of supplies.

Practically speaking, therefore, through our failure to recognize the importance of forestry in this country in pre-war days, we had to secure our timber requirements during the war at an extravagant price, paying high both for the material, for its extraction and conversion, and obtaining in the end a product very inferior to that on the markets before the war.

Further, we had to cut considerable amounts of material which had not reached maturity, thus suffering a direct loss of valuable capital. 
68 TIMBER SUPPLIES DURING THE WAR

By September, Igr8, the fellings being made in home woods were at the rate of 92,23 , and 100 millions of cubic feet respectively per annum for the soft woods, hard woods, and pit wood.

At this rate of felling the balance of our woods were estimated by the Timber Supply Department to be able to furnish supplies for the following periods respectively:

\section{Stocks}

Coniferous Timber . . I-2 year (i.e. to end of rgrg approx.)

Hard Woods . . . 6-Io years (approx.)

Pit Wood . . . 6 years (approx.) 
THE AFFORESTATION PROBLEM DURING THE WAR

AlTHOUgH the war put an end for the time being to all the initial steps which were being taken for the advancement of forestry and afforestation schemes in this country, so far as these were dependent on grants from the Development Commission, the Treasury having withdrawn sanction to further expenditure for the purpose, it must not be supposed that all the work thus auspiciously started entirely ceased.

Planting at Lake Vyrnwy, at Talla, and at the Lanarkshire Camps Catchment Area continued on a small scale, and planting was also carried on in the Forest of Dean and elsewhere on Crown property. Nor did a few of the large landowners interested in the matter relax their efforts, at least during the first two years of the war. The total planting achieved was, however, unfortunately insignificant, and much of it was only done because nursery stocks of young trees, which had reached plantable size, existed, and it was undesirable that they should be wasted. By the utilization of German prisoners and aliens from the camps very much more could have been accomplished in this direction. 


\section{AFFORESTATION DURING THE WAR}

The Development Commission took the important step of making a grant with which emergency seed nurseries were started in the Crown woods in order to raise and have ready a considerable number of plants for use at the end of the war, when it was confidently anticipated labour would be available for putting them out. ${ }^{1}$ Nurseries of this kind were formed in the Forest of Dean, Windsor, New Forest, and elsewhere.

During the war the Commissioners continued to carry on their investigations and deliberations on the subject of the best method of carrying out a big afforestation programme as soon as the peace made such a programme feasible. As I propose to deal with that subject in detail later on, it is unnecessary to do more than mention it here.

It was thought at the time that a great opportunity of getting more planting done was lost when the Home-Grown Timber Committee was appointed. It would have been possible for Government to insert a clause in the purchase contract that all proprietors from whom they bought timber should commence to replant the areas as soon as felled over, a definite period within which the operation was to take place being laid down. Such a rule exists in many of the continental States. In many of these cases it was thought that it would be no great hardship, since the proprietors were receiving a greatly enhanced price for their wood, which in many

1 The present enormously enhanced price of planting stocks in nurserymen's catalogues is evidence of the great value of this step.-E. P. S., March IgIg. 
cases was unsaleable before the war. Such a stipulation would have also been of the greatest help to a deserving industry in the country--that of those nurserymen who devote their chief attention to raising young forest trees. The war found these men with large stocks of mature and maturing plants on their handswhich required a certain a mount of labour to grow and represented a considerable amount of capital. Considerations of expense, since big plants are unsuitable and also difficult to handle and plant out when it is a matter of dealing with them in large numbers, preclude the carrying over for many years of tree seedlings and transplants in the nursery. When they have reached an age, three to four years usually, or size I 8 inches to 2 feet, they must leave the nursery and be put out into the woods. If the nurseryman cannot sell them, since it would not be business to give them away, though generosity has been shown in this respect, he burns them, and the time, labour, and capital of four or five years' work ends in a dead loss. This is an appalling waste of capital, and there has been much of it since the outbreak of war, more's the pity. The argument was put forward that labour was not available, but during the first three years of the war no real effort was made to mobilise women. ${ }^{3}$ We now realize that they are competent to do planting work on all save the roughest ground. And the German prisoners were left to grow fat in idleness!

Against the immediate replanting of felled-over

1 I advocated the employment of women carly in the war. Vide British Forestry. Part IV. 
areas, the contention was put forward that it was necessary to allow such areas to lie fallow for several years on account of the danger of a particular weevil (Hylobius) which attacks and destroys young newly planted-out conifers. This idea has been current in the country for a number of years, and is only another illustration of the well-known axiom, that a " little knowledge," etc. The habits of the beetle were known; one of the continental methods of dealing with it was partially known. This method forbids making adjacent fellings and plantings in successive years entirely on account of the habits of this insect which I have not space to go into, nor is it material. But the continental rule applies to large areas of properly managed forest, and the rule can only be applied with success to such. In this country the rule, applied to the small separately owned and independently managed areas of woods, achieved no result. Because, even if a proprietor allowed the newly felled over area to lie fallow for four years, he had no control over what his neighbour was doing. Consequently, when he eventually planted up the area, having lost four years' increment by leaving it unplanted, as likely as not his neighbour had just felled a wood near the adjacent boundary, and thus provided a breeding-place for the beetles, who found no difficulty in getting over the boundary line, being possessed of legs and wings, and killing the newly planted young trees. It is extraordinary how such a fallacy can have attained the hold and belief it has. And it carried dire results in its train, for it actually encouraged methods of haphazard 
fellings all over the estate without any attempt at a concerted plan (which accounts to a considerable extent for the great wind damage done to woods in the past in this country). The areas felled over in one spot were also often more extensive than scientific forestry, for well-known reasons, would venture to prescribe. These tracts, therefore, not only grew a thick crop of bracken or coarse grass or briers, gorse, broom, and so forth, which gave much trouble, and cost an unnecessary expense to eradicate before replanting; but, owing to their size, their replanting was more difficult due to the excessive exposure to which the young plants were subjected. You can see this sort of thing all over the countryside to-day. The stretches of bracken or the tangle of brier, gorse, and broom look very pretty in the spring or autumn perhaps, artistically speaking, but to the trained eye of the forester they appear very dirty and hopeless.

The mention of the weevil damage of the past brings me to the insect danger of the present and future. Do we realize what the lumbering of the woods will mean, what it is going to result in ?

All over the country woods have been cut down. All that is utilizable in each tree goes to the sawmill. The useless tops of the trees, of too small size to have any commercial purpose, and trees which have not been worth cutting, have been left in situ on the area. Now, trees have a number of enemies to contend against, and amongst them some bad insect ones. I have mentioned the weevil. Another class are the bark beetles, who breed in, and the families 


\section{AFFORESTATION DURING THE WAR}

are raised in, the trees and green tops. In a favourable year the progeny run into many millions. You will say what matter, if they only confine themselves to useless trees and tops on the ground. But how about the time when there are no more tops, green tops I mean? The grubs will not live in dead ones, nor will the beetles oviposit there. We shall have reared a mighty host, and this host in self-preservation will attack the areas of woods, coniferous woods, left standing in the country. There can be little doubt that this problem will give trouble.

Early in the war, when it became obvious that heavy fellings would eventually have to be made in British woods, I made the suggestion publicly that it would be useful if careful records were kept of the amounts of material felled, its nature, locality in which grown, and so forth, since such a record would prove useful in future replanting. The collection of data of this nature was initiated by the Home-Grown Timber Committee and Board of Agriculture, and is still proceeding. The data collected should prove useful in the future, so far as they afford an indication to the correct species to be replanted on the felled-over areas and an insight into the possible best species to plant on neighbouring blank ones. The measurement of the cubic contents, a verage height, etc., of promising young woods felled over for pit props will prove most valuable as an aid towards the future preparation of yield tables for these species. The measurement of the volumes of the older crops is also, it is believed, going to afford valuable data in some 
instances. That this work has been carried on even during the stress of the great war reflects the greatest credit on all the parties concerned. It may be expected to provide us with data which, now that so large a number of these woods have been felled, would have taken a long period of years to collect.

A most important step during the war, taken with a view to a thorough reorganization of the management of the economic and industrial life of the nation, and to bring the resources both of pure science and applied science into a more intimate relation with this life (and amongst the industries new ones, we will hope, such as forestry), was the appointment by the Government of the Reconstruction Committee. Some of the best brains in the country are upon the Committee, and the recommendations which it sees fit to make, if given effect to, and it is not too much perhaps to confidently anticipate that they will be, should yield results of incalculable benefit to the nation.

The terms of reference to the Reconstruction Committee so far as they apply to forestry are as follows :

"To report upon the best means of conserving and developing the woodland and forestry resources of the United Kingdom, having regard to the experience gained during the war." 



\section{PART III}

\section{THE FUTURE}





\section{VI}

BRITAIN AND EUROPE'S TIMBER REQUIREMENTS

THE termination of the war has by no means ended our timber difficulties.

It had been estimated about the time the Armistice was signed that we had left in Great Britain supplies of coniferous timber, at the then rate of consumption, to carry us to the end of I9I9-the present year; pit-wood supplies for another six years, and hard woods for six to ten years.

And we and Europe have to face the reconstruction period not only at home, but in the devastated areas!

Contrast our position with that of our ally, France. She has possessed a well-organized Forestry Department for many years. She has had to fell heavily in her forests during the war. But these forests were under scientific management. The lines of export for the extraction of the material were in existence or were foreseen. The felling work could be carried out on an organized basis.

It was a very different position from our haphazard and extravagant-of necessity haphazard and extravagant-methods. In the utter absence of all system in the growth of our woods, the marvel 
is that the Timber Supply Department should have been able to cope with the business in the efficient manner it has displayed.

France still has forests of her own left. She is fully aware of her present position in timber supply matters. We are very far from being so. At the present moment there are probably few in the country who would be bold enough to say where we shall get our requirements from during the next ten years-or whether indeed we shall be able to procure them at a figure at all commensurate with that which we can afford to pay.

If we turn to the position of our enemies, we find it a very strong one. With the exception of our former ally, Russia, the Central Powers ended the war with the greater part of the most valuable forests in Europe within their boundaries. It is unlikely that they have drawn on the resources of these forests during the war years. They have helped themselves by felling the forests in the areas they overran. And have probably stored up large stocks of felled timber from the same source to sell after the peace-if the Allies permit such a proceeding.

Is it possible to form any idea of the amount of timber which will be required for reconstruction purposes in Europe alone after the peace? The figure is likely to be enormous. In this country the Government is pledged to a housebuilding scheme of large dimensions, and huge amounts of timber will be required to restart our timber industries, for the railways and so forth. In addition, throughout the rural districts very considerable amounts will 
be required for ordinary estate work-of which repairs to buildings and fencing alone are important items. Repairs of this kind have practically ceased throughout the country for two to three years.

The war has thrown a vivid light on our ignorance of what forestry really means to a country. It has shown that Commercial Forestry is a key industry upon which a number of other industries of importance to a nation are directly dependent, both in times of peace and during war. That without forests a nation in peace-time is at the mercy, both as regards its requirements and the price it has to pay, of the foreigner. In war-time it is in the position we have been going through.

If we carry out an a fforestation scheme of sufficient magnitude to give us a certain proportion of our supplies in the future, we shall still have to wait, say twenty-five to thirty-five years, for pit wood, and sixty to seventy years for timber from our new forests.

How are we going to procure our requirements in the coniferous soft woods which form the bulk of our demands during this period-we may put it at forty years-for the next forty years? Timber, pit wood, pulp, these are three important and necessary materials to our industries.

The chief countries, if we omit for the moment Russia, from which they have come to us during the past half-century have reached, or are reaching, the end of their virgin forests. Their exports must, therefore, commence to drop in a not-distant future.

Extensive as is our own Empire, its widely flung forest areas, very valuable economically speaking, 
consist chiefly of hard woods-teak, mahogany, and a host of other valuable woods. Many of these have, or are likely to have a commercial importance, but they come under the heading of luxury woods in contradistinction to the soft woods of the markets, of which, so far as we are concerned, Canada and Newfoundland represent the only Empire sources.

These soft woods form the chief demand of the European markets-I am not sure that I am not correct in saying of the chief world markets. They mainly come from America, Canada, and Newfoundland in the New World, and Russia, Sweden, Norway, France, Germany, Austria-Hungary, Rumania, and Denmark in Europe. A brief survey of the probable supplies available in these countries, and of the markets to which they go, will enable some insight to be obtained into the position which faces us. We will consider the countries in sequence.

The Nere World: America.-I have mentioned in a previous article that soon after the cessation of the American Civil War in I866 that country commenced to make tremendous strides forward, and we are all acquainted with that extraordinary rapid rise of hers in the industrial world. To keep her increasing industries going, she began to absorb more and more of her own timber and other forestry products. Her exports were still very large, it is true, since the timber merchant naturally sells in the best market, but her local consumption rose by leaps and bounds.

Lumbering had its origin in America, and it was in 
America that it reached its most gigantic proportions; for nowhere else in the world, if we except Canada, will it be possible to witness lumbering on the scale American lumberers operated during the latter half of the past century. The lumbering itself cleared immense areas of virgin forest off the country-side, but the results of the methods employed did even more. All promising young growth of no commercial value was destroyed during the fellings, and all the parts of the trees of no use commercially were left on the lumbered areas (which latter subsequently became covered with a worthless scrub), to breed out insect pests, especially bark beetles; and the attacks of these latter on healthy areas of forest, which they killed out, have been on a scale truly American-in fact, on a scale commensurate with that on which the lumberer was working. I have alluded elsewhere to our present danger in this respect from exactly the same cause. By the side of the American one our case is microscopic. But we have now even more to lose, because it is our all, than had America in the heyday of the great lumbering business when her forests were cut out with a recklessness which she is now bitterly rueing; and must continue to do so for many a long day to come.

Fires, often starting in the lumbered areas, also played almost as much havoc as the lumbering. Probably very nearly as large an area of these magnificent primeval American forests were 'burnt out in some parts as fell beneath the axe of the lumberer. In one way and another, by the axe, fire, 
insects, wanton destruction, and carelessness, by the nineties of last century America began to awake to the fact that even her vast forests, which she had regarded as inexhaustible, were reaching a stage when her industries could no longer be supplied from them.

The American Nation, so quick at appreciating economic conditions to their own advantage, were slow to recognize their position. In fact, they were incredulous-as incredulous on the subject that their forests could ever give out as British proprietors were that their own woods could ever be made to pay. Roosevelt was the first President to realise the position the country had drifted into, and the fine American Forest Department and the conservancy policy now in force are due to his energetic initiative. But the end of the century saw America alive to the position into which she had unthinkingly brought herself. She had eaten her cake, or the greater part of it. Her requirements in wood pulp alone (that eater of forest) were enormous, and she recognized that she was no longer self-supporting in that article, and would soon not be so in many others.

You may remember the controversy which reigned in Canada in the early years of the present century over granting a preferential tariff to America in wood pulp. The agreement was not made, luckily for us perhaps, but it was a fair warning to us as to which way the wind is likely to blow both in American and Canadian timber exports-in fact the way the wind, economically speaking, must blow. Remember, it is as essential to her great industries 
to get these things as to ours, and she will pay the price. And she is much nearer one big market, i.e., the Canadian one, than we are.

Now to glance at Canada.

Canada.-Canada has long been looked upon by Britain as a timber El Dorado. We know for a fact that she has a gigantic reserve of untapped timber of the soft woods so largely in demand. All agree that the Douglas fir forests of British Columbia are magnificent. That her forests of other species, spruce, white and red pines, hemlock, balsam fir, cedar (Thuja), and ash contain large amounts of fine timber. This may be admitted. The questions affecting us in this matter, however, are to what extent have the accessible forest reserves, economically accessible from the point of view of the British market, been cut out, and how is the future great competition by America in the Canadian markets likely to affect this country! Presumably the matter will be guided by the ordinary laws of supply and demand. Canada, we may infer, will sell her material, or the greater bulk of it, in the best market. This market, because the closest, will be the American one which obviously will be able to offer a higher price. A factor which exerted some influence before the war, that the timber merchants of this country preferred Baltic spruce to either American or Canadian because the former is a closer grained, more durable article, may be left out of account. We shall have to take what we can get in the future, a habit we have doubtless all acquired during the war. 
Now, opinions differ widely as to the accessible amounts of timber, accessible from our point of view, remaining in Canada. Quite recently an expert Canadian lumberer, working for a private firm in this country, who knows the Columbian and other forests well, having worked in them, expressed the opinion that, from the British point of view, the accessible material had been mostly cut out. I have stated already what is meant by accessible. It cannot pay us to take timber from a distant country like Canada unless the material is all water-borne. The freights of long railway or road carriage would kill it for our purposes, as we could not afford to pay the price. The timber materials we have been getting from America and Canada in the past have been almost entirely water-borne, if not quite so. In other words, they have been cut in areas where they could be floated out of the forests, and the concensus of opinion seems to indicate that most of this accessible material all over the world has now been cut out, or is rapidly approaching that state. Can we then depend upon obtaining supplies greater in amount to those we received from Canada in I9I3 during the next forty to fifty years at a price we can afford to pay? The other point, America will become a large importer of timber materials in the near future, for her replanting of the immense felledover tracts, which she has started on a large scale, will take much the same period of time to mature as ours (which we have not, moreover, begun). Can we expect to compete with her successfully in 
the Canadian market? You will say, what about a preferential tariff? Perhaps so, but it could only apply to a certain proportion of material. Canada will help the Mother Country to tide over the difficult reconstruction period which will follow the peace. Of that we may be sure. ${ }^{1}$ But even if Canada, with Newfoundland and Norway and Sweden, could be looked to to supply $50 \%$ of our requirements during the next forty years, we shall have to look elsewhere for the remainder.

These are the points for consideration with reference to the American and Canadian markets, and I do not think the position is overstated.

Nerofoundland.-Newfoundland will doubtless be able to maintain and increase her exports to us for a few years; the material in her forests is of small size, useful for pit wood and wood pulp. For the latter article we may expect competition from America.

Europe-We will now consider the European markets.

It is significant that $67 \%$ of our timber imports in IgI3 came from Europe. The European markets may, broadly speaking, be subdivided into twothe North European markets and the Mediterranean and Near East markets.

The North European Markets. - This area may be taken to be that comprised in the White Sea and

1 Since the above was written, it was announced at the beginning of this year (I9I9) that the Canadian Trade Commission, through the Controller of Timber Supplies in this country, had arranged the purchase from Canada of $I, 000,000,000$ square feet of timber within the next twelve months. 
Arctic Ocean ports, North Sea, Baltic and English Channel ports; and the west coast of England, Scotland, and the Irish ports. The western coasts of France, Portugal, and Spain fall within this area and also into the Mediterranean one.

The forests supplying these ports were Russia, Sweden, Norway, Denmark, Belgium (before the war), France, and Germany; with smaller amounts from Portugal, Spain, and Austria-Hungary. Of these countries, the most important are Russia, Sweden, Norway, Germany, and France. Russia sent us the most and France the least in I9r3. The rest of the countries enumerated are negligible for our present purpose. We will consider the above five in sequence.

Russia.-Russia sent us something over a third of our total forestry imports in I9I3. She had taken the lead of the countries exporting to us, displacing Sweden, who formerly held pride of place. Russia has vast untapped forests of soft woods, covering a larger area than any other country in the world can show. The areas comprise some thirteen hundred odd million acres, of which $447,500,000$ acres fall in Russia in Europe, $62,800,000$ acres in Finland, whilst Siberia and Turkestan have $853,000,000$ acres. $^{1}$ We are only concerned here with the northern part of this area-i.e. North European Russia, Finland, and Northern Siberia. This great tract of country contains vast forests of soft woods (pines, firs, and larches of the trade)

${ }^{1}$ I have dealt with these Russian forests in dotail in Part II of Britisk Forestry. 
of the finest quality probably existing in the world. The more accessible areas have been worked to furnish the growing export trade with Britain, Germany, and other North European countries. But a fringe of the fine forests has, however, been touched, a mounting in value received on an average to a few kopecks per acre only for the more accessible areas. The rest were classed as inaccessible a like by the late Russian Government, who took no steps to open them out owing to the absence of the necessary capital, and by timber merchants, who stuck close to their old methods of extraction, and were shy of tackling new fields.

The material is there, and I propose to return to Russia later on.

Sweden.-For years past Sweden has remained one of our chief suppliers of soft woods. These imports commenced in the middle of last century, when she took up the trade. With the removal of our import duties on foreign timber in I866, Sweden's opportunity arrived, and she spent a large sum of money in opening out her forests, by the improvement of her river beds and waterways, to permit of timber floatage, and in the erection of extraction works to enable the timber to be got out by cheaper and quicker methods. The Government also initiated a system of fifty-year leases to timber merchants, and a form of lumbering sprang up in her forests which persisted for half a century. It was only early in the present century that the Swedish Government realized that she was killing her goose ; that the old lease policy was a fatal one to the main- 
tenance of her forest area. Since this realization the State has made considerable efforts to put an end to the wholesale lumbering. When the fiftyyear leases began to fall in, she refused to renew them, even in cases where their owners, the big lumberers, recognizing that the era of replanting had dawned and would be profitable, offered to replant them. Many of these men had acquired large areas of forest land by private purchase in former days, and the State became alarmed at so large an area of the country being in the hands of these trading firms. A law was passed preventing them from acquiring any more land in the country. It is impossible to go into the Swedish position in detail. But the outcome, as it affects ourselves, is that there appears little probability of the Swedish exports to this country remaining at their I9I3 figure for any length of time. The extensive areas felled-over under the fifty-year lease system, from which the imports received in this country were mainly derived, and which consisted of the most accessible and the finest forest, were left unplanted by the lumberers and their replanting has only just commenced. The State forests are of considerable size. But they are far more inaccessible, and consist of poorer quality material.

Norway.-It has been an accepted idea amongst experts for some years that Norway has been overcutting in her forests-i.e. cutting out more annually than was being put on in increment by the unfelled areas-for some time past. Both Norway and Sweden have taken full advantage of the high war 
prices to export material to the belligerents. It is not easy to estimate her exact position, but lumber. ing has been going on in her forests for several decades, and we know that most of the accessible areas have been felled over, and the only question which remains undecided from our point of view is how long she will be capable of maintaining her exports to us on the I9I3 basis. That this period of years will be short is a foregone conclusion.

Germany.-It is too soon to discuss the German forest problem. The world is fully aware that Germany has fine, well-conserved forests of a large size. It is probably not so well aware that to satisfy her large industries (or to keep as large an area of her own forests intact for an emergencythe war emergency) she was a large importer of timber, especially from Russia, on whose markets she had obtained a strong grip. The world is equally aware that Germany has helped herself to and ruined the Belgian forests, also those in parts of France and in Poland. My own opinion, which I have ventured to express to our Government, is that a part of the indemnity to be extracted from the Continental Powers should be paid in timber, and timber calculated at the prices in force at the outbreak of war-not those which may prevail at the peace : for which it is quite on the cards Germany has been hoarding up her forest wealth. Both Germany and Austria-Hungary have a fine hoard of this timber in their forests, and doubtless they have been hugging themselves in the belief that they will be able to take advantage of the high prices, 
or even to take command of the European timber markets, which they are of course aware are thoroughly disorganized, at the peace, and keep prices inordinately high. German organization is almost certain to have foreseen this state of affairs to some extent, and she must not be allowed to take advantage of a position she has herself deliberately created.

But for ourselves, any indemnity in timber or any arrangement come to on the subject of enforced export of timber from Germany to the Allies after the war would go primarily to Belgium, N. France, and presumably Poland, which would require all they could get. It would not help us, since Belgium, for instance, was self-supporting in timber before the war, and even exported to us.

France.-The chief timber material sent to us by France before the war was pit wood, with small amounts of sawn soft timber and timber manufactures. In how far we shall be able to depend upon them after the war is a doubtful problem. If we can obtain the pit wood, it should satisfy us. In any event, France will become an importer of forestry materials to a far greater degree than she was before the war, as she has had to make heavy fellings in her forests. We shall meet her as a competitor in these North European markets. In how far this will be so will depend on what arrangements we can make with her. For France can more easily draw upon the Mediterranean timber markets!

Belginm.-Belgium must necessarily after the war be an importer of timber, and will thus be a new 
competitor to us in the North European timber markets.

The Mediterranean and Near East Markets.-At first sight it may not be apparent why the Mediterranean and Near East markets should exert any influence upon British ones-i.e. the North European ones-although they would of course affect our Empire ones-e.g. Egypt; but the extension of the war and the entrance of Rumania has altered to a curious degree the position, for the chief suppliers of the timber markets of the Mediterranean and Near East, which absorbed before the war about $£ 20,000,000$ of forestry materials, were AustriaHungary and Rumania, and to a lesser extent Russia, a fact probably not generally appreciated in this country. The countries taking these materials were Turkey, Bulgaria, Serbia, Greece, Persia, Egypt, Italy, Spain, the South of France, and her African Colonies, Algeria and Tunis.

It will be obvious that the Mediterranean timber market has thus become thoroughly disorganized as a result of the war, and is likely to remain so for some time afterwards. Look at the chief suppliers, Austria-Hungary and Rumania, and the large number of treeless countries dependent upon this market for their timber requirements.

I had an opportunity of instituting a few inquiries into this matter in IgI6 whilst on active service in Macedonia. Salonika is the only timber market for Macedonia and Albania, building timbers being in chief demand. Materials from here were also sent up the railway to Monastir and Uskub in 
Serbia. The Serbian forests in the mountains, according to General Wassitch, then commanding the 3rd Serbian Army, should some day in a not distant future prove utilisable if, as is to be hoped, they have not been much damaged by the Bulgarians, who cut down most of the orchards of the country in the lower ground.

Let us glance briefly at the chief countries supplying materials to these markets.

Austria-Hungary.-The chief forests from which Austria-Hungary drew her supplies for the Mediterranean and Near East markets are situated in Bukowina and Galicia. In order to capture the Mediterranean markets, Austria raised a loan of $3,000,000$ florins in the nineties, which she expended in opening out the forests of these regions by clearing the river beds for floatage purposes, building narrow gauge lines, erecting sawmills and so forth. Her timber and exporting merchants also combined and succeeded in obtaining from the Russian Government low freights for timber carriage over the Russian railways, and equally low freights from the Russian Steamship Navigation Company for carriage of timber to Odessa. The timber from the Bukowina Mountains was placed on the railway at Novoselitsa and railed to Odessa, and shipped from there to the importing countries. Thus Russia, who has, as will be shown, magnificent forests in the Caucasus and on the Black Sea littoral, was actually assisting her rival to cut out Russian timber exports in this market, a matter which has now a considerable importance and significance. 
Austria's timber merchants also exported their timber by the Rumanian railways to Galatz and thence by sea. After the peace the areas in which Austria developed this forestry export trade will be in new hands. The present condition of these fine forests is doubtful. In any event, great damage is certain to have been done to the export works, and disorganization appears to be only too probable for some time after the war before the threads can be picked up. The export trade may also be badly hit by the improbability of the new Rulers obtaining either from Russia or Rumania the low freights Austria enjoyed, and that would almost certainly reduce the exports enormously.

Rumania.-Since the nineties of last century Rumania had made great strides in opening out her forests so as to make a bid for a larger share in the Mediterranean markets, in which at the outbreak of the war she held second place. She had devoted considerable sums of money to improving her means of extracting the produce, and in its subsequent transportation. She was also offering forty-year timber leases with the object of attracting capital. After the occupation of so much of her country by Germany and Bulgaria, the state in which the forests are likely to be left, or at any rate all the accessible ones, is open to doubt, or, perhaps one may say, knowing the methods of these barbarians, is not open to doubt. At the least it is likely that they will have destroyed all the timber extraction works, since their ally Austria had been in competition with Rumania in the 
Mediterranean markets, and was unlikely to lose such a favourable opportunity to get rid of her rival in this manner for a time.

Russia.--Russia is at once the most disappointing country in this Mediterranean trade, of which she only supplied about one-sixteenth before the war, and the greatest hope of the future so far as it is concerned. She could easily supply nearly the whole of the tradefrom her great reserves of forests, a mounting to some $18,000,000$ acres in the Caucasus and along the Black Sea littoral, these forests chiefly belonging to the Crown. The forests consist of beech $(25 \%)$, oak ( $16 \%$ ), elm (I2.8\%), pines $(8 \%)$, spruce $(6.6 \%$, chiefly in the Black Sea Maritime Province), and Caucasian fir (A. Nordmannia) $(6 \%$, of which there are large forests in the Black Sea district). ${ }^{1}$

The forests consist mainly of trees I50 to 200 years old, some 200 to the acre on an a verage. These forests are to all intents and purposes unexploited, except a strip along the Black Sea littoral. When these forests are opened out, they will inevitably have an effect in reducing the strain upon the North European timber markets, and will not improbably affect favourably in this respect the world markets. Too much stress cannot be laid on this point of view, and a glance at the map will demonstrate the truth of the contention.

Now, if the above brief analysis of the position of the European countries and the markets upon which they depend for their timber supplies is any-

1 Vide Part II, British Forestry. 
thing approaching correct, it will be apparent that there is grave reason to fear that we shall witness a permanent drop in the exports of some of the chief suppliers of the North European timber markets in the course of a few years, if not in a very near future. Further, there is every appearance that the disorganization of the Mediterranean and Near East timber markets will not cease with the signing of peace, but is likely to cause trouble for some time.

Finally, we know that the demands for timber at the peace for reconstruction purposes must prove enormous. Where is all this material to come from ? And with that problem settled, where are we going to obtain our annual supplies from in the future, supplies absolutely essential to our industries, as we have learnt only too well during the past four years. There must be a shortage in the markets from the causes I have already explained, and we shall have new competitors.

The country which stands out in the above enumerated list is Russia. Russia, who stands astride both sets of markets, North European and Mediterranean and Near Eastern. Russia, from a forest point of view-I will not say lumbering point of view, because we do not want any more lumbering qua lumbering, and it is not necessary-Russia, as we have seen, has enormous areas of untapped forest containing the class of materials, the soft woods, which form the larger part of our imports; and incidentally those of the Mediterranean countries, which can be supplied from the Caucasus.

North European timber markets are the ones 
which chiefly concern Great Britain. In these the great North Eastern forests of Russia are bound to play a leading part during the next forty to fifty years. Archangel and the New Murman ice-free port, with, in all probability, others further east, will be the chief exporting centres. Riga and other Baltic ports are unlikely to show in the future anything like the amount of their timber exports of the past. For one thing, some $16,000,000$ acres of forest have been destroyed on the Eastern front in the fighting zones in the basin of the Western Dvina, Lower and Northern Dnyepr, and in Lithuania, and the opinion was strongly held in Russia in IgI7 that the Russians would keep the timber remaining in this part of the country for their own reconstruction work and refuse to allow its export in any quantity. The zone of the main timber exports from North Russia has then shifted to the White Sea and Arctic Ocean, and a portion at least, probably the larger portion, of our timber imports must, I believe, come from here.

After a close study of this problem I again visited Russia in I9I7, went up to Archangel, and from there visited some of the forest areas on the Upper Northern Dvina and Vitchegda. The forests of pine and spruce in these regions are enormous in extent and very fine. All that is required is capital to open them out. We can either go and get the material ourselves; or we can remain dependent on the foreign capitalist (not the Russian, for he has no capital) and pay him the middleman's charges and profits. 


\section{RUSSIA}

The details of the manner in which we should be able to obtain a portion of our supplies from this region would not necessarily prove of interest to the public. But it is of importance that the public should appreciate the fact that the timber problem is not an easy one at present; is not likely to grow easier for our children and grandchildren; and that consequently it has a direct bearing on the afforestation problem in this country and the manner in which this problem requires to be faced. 


\section{VII}

IVHAT AFFORESTATION WILL DO FOR THE PEOPLE

IN a preceding article our position, both as regards the absence of commercial forests in the country and our consequent total dependence on imports for our timber requirements, has been depicted.

We now come to a consideration of the afforestation question in its various aspects. It is proposed to review the steps by which. we may endeavour to remedy for our children and grandchildren our present unenviable and difficult position.

It may be premised at the outset that the advantages to be obtained by the mere planting up of our waste lands are not the only ones which will accrue to the nation by undertaking this urgent reconstruction work. There are others.

The man in the street will ask, is probably asking, What is all this talk about afforestation? It means spending more money, does it not? Is there any need for it? What will it do for me or for the general welfare of the people of these islands?

The answers are many and various, but there is one which transcends the rest. The planting up of the derelict lands of the country will be directly beneficial to a considerable section of the community if undertaken with foresight and prudence.

The planting question in Great Britain is not IOO 
merely a matter of providing pit wood for the collieries-important as this side of the question is.

It is not merely the economic necessity from the national view-point of putting to their best use the waste lands of the country, the present position of which is a national disgrace.

It is not merely a matter of saving some part of the sum of $£ 60,000,000$ to $£ 70,000,000$ sterling going out of the country into the pocket of the foreigner to pay for timber imports.

It is not merely a question of providing for a future emergency by having in the country sufficient timber to tide over a period of stress such as we have passed through during the past four years-though the urgency of this view-point should have become apparent to all.

It is not only a matter of providing additional work for the rural population, and so improving their social conditions, urgent as this aspect of the problem has become.

The importance of the afforestation question is intimately connected with all the above points. But we place it on a higher plane, and give it its proper position in the economy of the nation, when we consider it from the aspect of the improvement in the social conditions of life of the rural inhabitants it may be made to result in. With an improvement in these conditions you will stop wholesale emigration from the rural districts, such as was taking place before the war, increase the head of population on the country-side, and increase accordingly the virile strength and members of the nation; whilst at the 


\section{IO2 AFFORESTATION FOR THE PEOPLE}

same time filling up the areas of the country at present but sparsely inhabited.

This question, the improvemert of the social condition of the rural population, is as much a matter for the consideration of Labour and their representatives as it is for the other classes of the community.

It is not claimed that afforestation by itself can bring a bout the a bove desirable results. It will not.

The main industry of the rural districts is, and will always remain, agriculture. In the parts of the country where large areas of a poor class of soil exists, agriculture has not been able to provide sufficient employment to any considerable head of population on a decent living wage in the majority of cases. If therefore by some form of cultivation these areas can be made to provide work and the amenities of life to a larger population, the nation will be the gainer.

How can this object be attained?

The answer lies in the proper combination between agriculture and forestry, a point to be dealt with in a subsequent article, and a certain sum of money will require to be allocated for the undertaking. But some of the advantages, indirect advantages they may be termed, if you will, to be obtained from the outlay are indisputable. The social aspect is one and not the least important.

The planting up of the existing wastes will necessita te the employment of a certain head of population. The work of superintending the plantations and so forth will provide employment for a certain permanent head of labour. 
Accommodation for this population does not at present exist in these districts. How is it proposed to provide it ? Small holdings, which will be alluded to later, are one of the ways - the chief, in all probability. But how are these to be located ? It will not suffice to jot them down promiscuously at varying intervals apart, and in such a fashion that the occupants are debarred from enjoying modern-day amenities of life-the social conditions now demanded, and justly demanded, by the worker. It might have been attempted before the war, but its success would have been doubtful. But the men and women who will be returning to the soil from the war or from the industrial centres throughout the country where they have been engaged on war work, will require the amenities of life to be a vailable in the areas in which they undertake future employment. The forest worker, whose life at the best is a more lonely one than that of other industrial workers, will want to have within reasonable distance of his centre, church or chapel, shops, school, cinema, and other recreations, or he will never be retained. He will demand decent surroundings, and to be able to bring up his family properly.

The provision of these present-day necessities in the life of the worker requires to be definitely recognized in the afforestation scheme. Equally definitely must recognition be accorcled to the point that a living wage throughout the year must be forthcoming for the forest worker as for the agriculturist. The difficulties of providing a whole-time wage for all the workers required in agricultural 


\section{I04 AFFORESTATION FOR THE PEOPLE}

operations throughout the year is well known. A certain head of additional labour is required at certain seasons for whom no employment is a vailable on the farm at other times.

Well, the same is true in forestry, and even more so, and the slackest periods in agriculture are those when the forest management demands the greatest amount of additional labour.

The significance of this fact becomes at once apparent.

With a proper combination between agriculture and forestry on a country-side, a sufficiency of labour is assured for both industries at their several seasons ; both industries can depend on obtaining a labour force cognizant with the work to be done; the labourer is assured of a whole-time living wage throughout the year, with a bit over with which he and his family may enjoy some amenity in a rather hard life; and finally, by associating the agricoforestal colonies in settlements, they can enjoy conjointly the modern-day social necessities of church, school, shops, recreation-hall, and so forth.

To those in timately a cquainted with a country-side and the present-day requirements of the rural inhabitants, the above exposition of the case will appear self-evident. But it is of the first importance that those who have charge of the afforestation business, and the public who have to pay for it, should realize to the full the altered conditions in the rural districts.

You may start planting schemes by means of imported labour-they must be so started-but 
afforestation in this country will never proceed any length by those means. A contented agricoforestal population must be settled in the forestry areas ( $I$ am alluding to those of any size), and this will only be possible by giving the social conditions and requirements of this population a recognized position in the undertaking.

This is the case for the individual worker. But the afforestation question has a wider scope. By afforesting a considerable area of the waste lands at present providing scanty employment to a sparse population, you create a new source of labour supply, you settle on these areas, and consequently retain in the country, a hardy population, an overflow from the more densely populated districts.

And with the increase of the forest area and purely forestry work will arise minor forest industries, dependent upon the forests for their raw materials, which will provide work for an amount of labour far in excess of that which the management of your new forests will maintain. And these industries will increase the rural prosperity.

As examples of such industries may be mentioned turnery of many articles of domestic use, now brought from abroad, the manufacture of cask hoops, bobbins, hurdles, spokes, toys, and the many other uses to which small woodwork can be put with the aid of the simplest machinery.

These are some of the social aspects of this question, and their importance from the view point of labour is undeniable. 


\section{VIII}

WHAT AFFORESTATION WILL DO FOR THE NATION

WHAT are the other benefits which the introduction of commercial forestry in this country is going to give you? They have been alluded to briefly in passing in the preceding pages. A short summary of the more important will be of interest.

You will see I use the term "commercial" forestry. During the nineteenth century the significance of the expression was almost lost sight of. We possessed a considerable knowledge of arboriculture and horticulture, as the beautiful parks and policies existing on estates throughout the country well evidence. We also knew how to plant shelter belts and clumps to afford shelter to the fields and stock of the agriculturist. But the existence of the main woods of the country served principally for sporting purposes. They were neither planted nor managed on a commercial basis, and the expenditure lavished on them was only to be justified if the financial and other advantages derived from their maintenance were looked for in other directions (sport, amenity, and so forth) than the purely commercial one of the production of timber. 
Over and above the social aspects, what does commercial forestry propose to give the nation? Tersely expressed, it means the development of one side of the national resources of the colintry-the undeveloped resources.

What are these undeveloped resources in these islands? We have some $16,000,000$ acres of mountain and heath land of varying quality. Some of this area by reclamation may, in future, be used for the production of food-i.e. for agriculture. Forestry-commercial forestry-in the accepted definition of the term rules out from the sphere of its activities all land which can be used to increase the food supply of the nation. Nor does it take up land which in one way or another can be utilised for the supply of materials for any of the other more remunerative industries.

What commercial forestry aims at is the utilisation of all land, by growing properly managed crops of trees upon it, which cannot be made more productive by other means. Out of the $16,000,000$ acres above alluded to, there are probably at present some 5,000,000 which could be put to their best economic use by being placed under trees. In other words, although the return on the capital invested in forestry is low in comparison to other industries, yet this capital devoted to the class of land forestry can make use of yields a better return than anything else, whilst at the same time giving the nation other indirect advantages of an important nature.

What are these?

The war has brought one into great prominence8 
National Security. The stress of the past four years, the grave doubts as to whether our island supply of growing timber would prove sufficient to see us through the war, has brought the importance of the afforestation question home to the Government. The public, perhaps fortunately, has had little idea of the anxiety which, with the indefinite dragging on of the war, this problem caused those responsible for the absolutely essential timber supplies. National security-the necessity of having within these islands at least a sufficient supply of growing timber to carry us over an emergency such as we have just been through-a three to four years' supply of properly grown commercial timber.

A second reason, and one very nearly as important - to eliminate or mitigate our total dependence on the foreigner for our timber supplies. This dependence, as we have seen, has meant, and will mean for some years to come, that considerable sums of money annually leave this country for the purchase of timber, and, worse still, manufactured timber-sums of money which might have gone into the pockets of our own people. And the sums of money thus paid away will increase in the future with the cutting out and utilisation of the world's virgin forests. We shall have to buy and pay for planted timber, material from woods such as we could grow ourselves. The price of the material will be far higher than we have been paying during the last half century or so.

All the nations have become alive to the fact that the road to wealth and the surest way to successful 
development in the social progress and the amelioration of the conditions of life of their peoples is by the conversion and manufacture of their raw products, before export, within the country itself. By this means plenty of assured employment is provided for their own people, the money expended on the conversion and manufacture goes into the pockets of their own people, and is put there by the foreigner who has to purchase these imports. This applies to timber imports as much as to anything else. The export of unmanufactured or semimanufactured timber, which was a prevailing feature of the exports from foreign countries during the earlier portions of the last half of the nineteenth century, is doomed.

Further, as long as we are totally dependent on imports of timber, we have no control over prices. We are at the mercy of those countries who do possess forests. The possession of a considerable area of commercial forests of our own will alter this aspect of the matter-a most serious one for us, as the war has well exemplified. As long as imports of timber were possible during the war years, we were at the mercy of the foreigner in Europe, and had to pay him the price, the exorbitant price he asked. In two years we threw away $\$ 37,000,000$ in this way. They had a monopoly.

Lastly, the importance of commercial forestry as it affects the home-life and requirements of the people. Timber and its products play an important and intimate part in the home-life of every grade in society. We may take two instances which 


\section{IIO AFFORESTATION FOR THE NATION}

are causing serious inconvenience throughout the country at the present moment-the match and paper.

Could any one of us have imagined that a great war in Europe would result in the almost total disappearance of the match from the household ? Could any housewife in the wildest flights of her imagination have ever conceived it possible that in her daily or weekly itinerary of the household supplies, the match or its procuring would have to be exalted into a place of chief prominence? Could the average smoker have ever envisaged a future in which the match would disappear from his clubs, or that he would have to refrain from asking for the loan of a match from a friend or even a passer-by ?

Paper again. It was long, the war had dragged through some two and a half years, before it dawned on the country that their old lavish use and waste of paper would have to be abruptly stopped. Many of us will probably long remember the week which saw the withdrawal of the familiar newspaper poster from the street and railway stations. It brought home the war to the public of the towns as probably nothing else had done. The increase in price of the news-sheet, books of all degree, and writing-paper was another result. And nowadays 'he housewife treasures and hoards up in secret places the paper wrappers of the parcels she receives, and finds herself in serious difficulties in providing sufficient paper for a purpose which had never previously entered into her conception as one of the essential household provisions-to wit, the 
lighting of the household fires, even the reduced number which the coal shortage permits her to sanction. These are two homely examples directly brought about by the war reacting on the timber supplies.

In ordinary peace times, however, it is easy for every one of you to realise your great dependence on the products of the forest in the home. Take away the timber parts of your house, and you would find yourself devoid of floors, windows, doors, a roof and furniture, and numerous items of use in the domestic economy of your household too numerous to mention.

A number of industries, in the absence of their chief material, wood, would come to an end-have done so to a great extent in fact, during the latter part of the war.

Your various methods of locomotion, railway, trams and omnibus, carriage and motor-cars, and the new method, aeroplane, all demand wood in their construction to make them convenient and comfortable vehicles of transport.

In fact, throughout all the walks of our existence in their various degrees, luxury, utility, sport or bare necessaries, the products of the forests play an important part in the national economy of a nation.

The cheapness and abundance of these articles in their several degrees is entirely dependent on whether a nation possesses an adequate area of commercial forests of its own or rests dependent for its supplies on the forests of others. 


\section{IX}

FORESTRY AND AGRICULTURE

THE intimate relation existing between forestry and agriculture has been touched upon in a previous article.

The matter calls for some further brief elaboration. Agriculture is one of the oldest industries of the world, and forms the main industry of the rural districts. But, unfortunately, in spite of its unquestioned pre-eminence on the country-side, in the areas where the poorer classes of soils predominate, such as in the mountain and heath lands throughout these islands, for instance, agriculture by itself cannot be made to give an adequate constant wage to any considerable section of the community. On the comparatively small areas of land which can be cultivated it affords a livelihood, often a precarious livelihood, to the cultivator, which enables him to support his family usually in distressingly hard circumstances till they grow up. One of his offspring subsequently carries on the small farm. The others have to look elsewhere for a living. In the past the large neighbouring areas of what to all intent and purposes have remained waste land afforded them no prospects 
of obtaining employment. They do not do so at present. If they are utilised for sporting purposes, a few days' or weeks' employment in the year may have been procurable, but that was all.

Something more permanent has been required to retain on a country-side of this nature the sons and daughters to whom it has spelt all the home they have known. It has been their home, and has possessed all that indescribable fascination and attraction which the word has always possessed for the human race. But it has not proved a home in the neighbourhood of which they have been able to find work and consequently remain. And yet, had the nation managed things differently in the past, these children, those of them not afflicted or blessed with the British spirit of roving, might have spent their lives in their home surroundings: for it is just this class of land which this question of afforestation in the country is intended to deal with. It is the conversion of these lands, by growing commercial crops of trees upon them, into a national asset of the first importance that the afforestation schemes are advocating.

There is no interference with agriculture here. Rather the reverse. In course of time the afforestation of such portions of these derelict areas as are capable of such treatment at present will result in the extension of agriculture on areas in which it would have at present no chance of success. In such areas at the present day it is often possible to come across the ancient marks of furrows. No plough put in nowadays would result in any crop 
gladdening the eye of the farmer. And yet who farmed here in the old days? And under what conditions? The marks are unmistakable. Where is now a howling wilderness of heath and bracken or tussocky grass, pretty to look at, but worthless economically, crops were raised by our forefathers. The explanation is simple. In their day the neighbouring hills were covered with forest, affording the necessary shelter to these localities, and thus enabling them to produce crops of focd for man. In some cases, and they may be more numerous than can yet be surmised, through the restoration by replanting of the shelter in the form of commercial woods, the extension of the area of the food-producing lands may be attainable.

The relation between agriculture and forestry, in the absence of all real forests in this country for several generations, meets with little recognition as yet amongst the public. The farmer realizes the value of shelter belts for the protection they afford his fields and stock. The townsman and the majority of country people have regarded the woods as mairly kept up for sport or amenity purposes. The close affiliation and interdependence of agriculture and commercial forestry has not been understoodis perhaps scarcely appreciated by the bulk of the population at the present time.

We have shown that commercial forestry starts with the recognition that the forest has no claim to the utilization of all land which can be used by the agriculturist, with the exception of the small areas required as nurseries for the raising of the 
young trees to be subsequently planted out to form the woods.

The enunciation of this definition of the class of land required by the forester at once removes the suspicion of the agriculturist that the former is aiming at alienating, for forestry purposes, a part of the lands whose correct position in the economy of the country falls within the purview of the agricultural industry.

But commercial forestry does more than this. It affords direct assistance to the farmer in helping him to maintain an efficient labour staff. The farmer employs more labour, when the raising of crops is the chief object, than is required in forestry. In the case of the sheep farm the reverse is the case. Farm work and forestry proper dovetail with one another in a most satisfactory manner for both industries, and illustrate a merveille the interdependence of the two in those parts of the country in which forestry, owing to the poor quality of the soil, forms the staple industry. In the winter season farm work is at its slackest. There is little to be done for the part of the labour which may be termed the migrant part, and therefore but small wages can be earned. This reacts both on the farmer and the labourer. The farmer cannot afford to pay wholetime wages to a portion of his staff for whom he cannot find full employment; the latter, finding it impossible to live and maintain a family in default of an adequate wage throughout the year, leaves the country for the town or industrial centres, or emigrates, During the past few decades before the 
war, as many are aware, this state of affairs, with the growing demands on the part of the labourer for an amelioration of his conditions of life, quite justifiable demands on his part, had been becoming increasingly difficult for the farmer, and a serious problem for the country. But if the farmer has been feeling it increasingly difficult to obtain the extra labour he requires at certain seasons, what would be the experience of the new afforestation schemes if the labour required had to depend on forestry alone to provide it with whole-time work? For the considerable staff which would be required at certain seasons it would be impossible to provide wholetime work, and consequently a wage, throughout the year. The bulk of the heavier forestry work is done during the winter and early spring-i.e., when the weather is most unfavourable for farm work. If the afforestation schemes were to rely solely or even to a great extent on temporary imported migrant labour, it is extremely doubtful whether it would be possible to recruit this labour over any long period of years. It would not be a satisfactory type of labour, nor would the afforestation schemes be likely to catch hold in the country or awaken interest in the localities in which they were undertaken. It is vital that such interest should be aroused and maintained.

In order to stop the serious emigration from the rural districts before the war a remedy was sought in the Small Holding Act, under which individuals were to be settled on small areas of land which they were to cultivate themselves. The war has raised the small holding into a position of the first import- 
ance, since it affords an opportunity of rewarding soldiers for good service, by settling on the land those with a liking and aptitude for rural life. It will also be a factor of the greatest importance in the afforestation schemes. The consideration of the small-holding question is only here regarded from the latter aspect, and with reference to the lands utilizable for afforestation. If the farmer in these districts is unable to provide sufficient whole-time labour to maintain the rural population on the land, the small holding, with its smaller area, cannot provide sufficient work throughout the year to employ the holder or enable him to live and support a family in decent conditions. The average small holding, where two to three cows are kept, will include sufficient arable land to provide the small holder with crops for his family and stock. The cultivation of this area can be done by devoting a few whole days to it in the spring and autumn, and afternoons at other periods during the year. Such holdings, certainly in the tracts of country which the afforestation schemes are likely to be developed in, cannot be made to support the occupant in the absence of any subsidiary permanent occupation. Organized forestry occupation will provide the holder with the means of living a life of comfort, and give him the little extra in wages which is now accepted as the minimum the labourer has a right to demand.

The term "forest village," which is merely a collection of small holders settled as a community, is well understood in some countries, the village being a settlement within, or adjacent to, the boundaries 
of a tract of forest. The inhabitants of the village are permanent employees in the forest, and enjoy certain privileges with reference to the right to forest produce, either free or at reduced rates, and have a certain area of grazing-lands allotted to the village community as a whole in addition to each villager having sufficient arable land to raise the crops necessary for his family and stock. By means of a co-operative system all spare produce could be marketed. The occupants may even own a portion of the forests in the neighbourhood in joint ownership, and work it as a communal forest. This is, in fact, the principle of the small holder combined with the forest worker, and if applied in this country, it would enable the small holder to live the social existence demanded by the present-day labourer, a point already alluded to in Article VII.

It would also give some assistance in the matter to be referrred to later, of taking up the winter grazing-lands, which will form the bulk of the plantable land in some parts of the country, and the rougher ground at the higher elevations used for summer grazing, which may have to be taken up along with the other in many instances, although at present above the planting level, since the summer grazing loses its chief value unless it has the wintering attached to it. A block of land, including winter and summer grazing, could be made over to the small-holder village, and to the larger farms in the vicinity, to be used conjointly. For this purpose the size of the small holding will require to be definitely defined. At present under the Act all holdings of 
rental value of $£ 5^{\circ}$ or under are included, or may be included, as small holdings. In some parts of the country I,000 acres or more of rough ground could be obtained for this sum. Such an area can scarcely be termed a small holding, although it could well be attached as summer grazing-ground to a collection of small holders settled on the arable land.

A further difficulty in the creation of the small holdings is connected with the erection of the buildings. The increase in the cost of building and materials is most serious. In connection with the afforestation schemes it may be suggested that temporary buildings might be put up on the areas selected for small holdings, to be replaced, as materials and prices become easier, by permanent ones. This would save the wasteful expenditure on jerry-built cottages, run up in a hurry, with the inevitable dissatisfaction they would give rise to. It would probably work out cheaper in the end, and would result in the afforestation schemes being carried out at a quicker rate, thus affording more labour for demobilised men and women.

The foregoing remarks are intended to bring out the intimate connection which exists between agriculture and forestry. On the country-side the two are so inextricably woven together in all countries where commercial forestry forms a part of the economic life of the nation, as to render this recognition one of the important factors in any afforestation schemes which are to be undertaken in this country, for the success of such schemes is dependent on their being put into force with the 


\section{I20 FORESTRY AND AGRICULTURE}

assistance of the agricultural authorities. Friction between the agricultural and forestal authorities will inevitably occasion delay in the operations of the latter, and will be prejudicial to the smooth working which is an essential to the amelioration of the conditions of life of the rural populations of the districts whose improvement the afforestation scheme should contemplate. 


\section{$\mathrm{X}$}

THE PROTECTION OF THE AFFORESTED AREAS

IT would be a useless waste of public funds to carry out an afforestation scheme of any magnitude throughout the country unless adequate steps were taken to protect the woods created against the dangers to which such property is exposed to a greater extent perhaps than almost any other class.

These dangers may arise from the action of man, or may be due to the attacks of mammals, birds, insects, and noxious fungus pests.

Special legislation is usually required to protect the forests from these dangers, and exists in all countries where commercial forestry forms one of the national industries.

\section{Pronibition against the Acts of Man}

The protection afforded by means of the power to prosecute the trespasser or the man who has committed a small theft within a forest area is not sufficient for the safeguarding of forest property. The laws in force in a country would punish acts of this kind by a moderate fine or a short period of simple imprisonment. If through the carelessness of the individual whilst committing the trespass 


\section{I22 PROTECTION OF AFFORESTED AREAS}

or theft the forest was set on fire, and a considerable area burnt, a heavy punishment, or one commensurate with the actual loss of property and capital involved, could not be inflicted under the ordinary criminal law of the country.

To adequately protect forest property it has been realized that special laws are necessary, enforcing heavier punishments for acts which, though small in themselves, and committed either through carelessness or with no deliberate intent to cause heavy loss, have resulted in serious damage to the forest property.

In this country a considerable part of the afforestation scheme will deal with the growth of conifers. This class of forest, and more especially in its younger stages of growth, is most subject to danger by fire. Hundreds or thousands of pounds' worth of damage may be done in a few hours by a careless act or as a result of trespass without intent to cause harm to the forest area. How is it proposed to protect young plantations of this nature existing in the neighbourhood of industrial centres, collieries for instance, under the existing laws ?

Railway engines are a constant source of fires in the woods of this country; and yet the compensation the courts are able to grant the owner of the wood at present is often out of all proportion to the damage which may have resulted.

Again, cattle, horses, sheep or goats, getting into a young plantation through the negligence of their owners, may commit irremediable damage before they are discovered and ejected. This damage may 
result in the larger part of the plantation having to be replanted, and may involve the loss of several years' increment, which in plain English means that the wood will be so many years longer before it reaches the age at which it will be ultimately felled and yield the pecuniary return on the capital involved. The damage caused is therefore not only the material injury to the young trees, but results in an eventual direct monetary loss in addition to the extra outlay necessitated in replanting the area damaged. Is there a law in existence capable of inflicting punishment commensurate with the offence or of affording the essential protection to forest property?

The above examples, common enough on the country-side, will suffice to show that it will be necessary to pass a simple special Forest Act in this country if adequate protection is to be afforded to forest property in the future.

\section{Protection against Domestic Animals}

Domestic animals, such as cattle, horses, sheep, and goats, cannot be admitted into young plantations. Cattle browse on the young trees, especially hard woods, and through their mere weight break down the young plants.

Horses are very prone to gnaw the bark of hardwood trees, as has been exemplified in France and elsewhere during the war. The horses were picketed under trees to hide them from aeroplanes, with the result that the bark on hundreds of thousands of trees was gnawed off as far up as the horses could 


\section{I24 PROTECTION OF AFFORESTED AREAS}

reach. This habit can be easily seen in the case of trees standing in or on the edge of paddocks and grass fields in this country. Sheep and goats both cause damage in young plantations-the former owing to their habit of bunching together and stampeding when frightened; the latter owing to its omnivorous propensities. The goat is considered to be one of the most destructive of all domestic animals in the forest.

Fencing of the young plantations will be necessary in localities where domestic animals of these classes are numerous, and are subject to being moved about the country at certain seasons of the year in herds or droves, and the adequate supervision of the animals whilst in transit must be enforced by law. From, roughly speaking, the twenty-fifth to thirtyfifth year onward, the danger from these animals, with the exception of the horse, ceases.

Game animals will be alluded to later.

\section{Protection against Animal (Mammal) Pests}

Amongst the foremost of the animal pests comes the RABBIT. The damage caused is due to its habit of gnawing the bark of young plants, an operation which the formation of its dental system is admirably adapted for. If you look at a rabbit's teeth, you will see that the two middle ones in the upper and lower jaw are prominent and have chiselshaped edges. Moreover, the pulp at their bases does not dry up, as is the case with most teeth, but persists throughout life, and the teeth consequently continue to grow in length until the individual's 
death, thus replacing the chisel-edge which is continually being worn away by use on hard surfaces. The power, therefore, of the rabbit to commit damage on young tree growth, to girdle and kill young trees, becomes obvious. If we add to this the great breeding powers of the rabbit - several litters from five to eight in each being produced in a year-we see why this animal is such a pest on the country-side. A young plantation may easily be killed right out in the course of two to three years by rabbits if left unfenced and netted. The damage committed is greatest when the ground is covered with snow, the rabbits then seeking their food from the bark of young woody plants. It is also at this season that the rabbit searches for and devours young natural seedlings which have developed from the seed fallen from the trees during the past season or two.

Were it not for the rabbits, with the admirable climate possessed by this country for forestry purposes, it is not too much to say that in many parts it would be comparatively easy to regenerate the woods by means of this seed (i.e., with the young trees developing from it) instead of planting up the areas artificially after the removal of the old crop of trees. It is this animal chiefly who, year after year, removes during the following winter the thick crop of germinated seedlings which may be seen during the spring, summer, and autumn following a good seed of the particular species of trees. ${ }^{1}$

The rabbit is just as great a curse to the farmer

1 See British Forestry, page 42 , plate 9. 


\section{I26 PROTECTION OF AFFORESTED AREAS}

It feeds on his young grain crops as they come up, on his young new grass areas, and in many parts of the country ruins the rough grazing areas, these tracts being so overrun by this animal that stock cannot live upon them.

This is a heavy indictment against the rabbit, but it will be corroborated by every forester and farmer in the country.

So far as forestry is concerned, the rabbit must be exterminated on the arcas devoted to the commercial aspect of this question. But something more than this will be required. Up to now it has been imperative that before a young plantation has been formed the area should be fenced and netted against the rabbit, thus materially adding to the cost of formation and throwing an unjust burden, financially, on the plantation. Even if a small proprietor cleared the rabbits off his own land, he has still had to fence his plantations against the rabbits kept up by his neighbours. For, probably owing to their great breeding capacity, the rabbit is endowed with a remarkable flair for "clean," i.e. rabbit-denuded ground, and will quickly take possession of it. Females carrying young are particularly addicted to searching out areas of this nature to place their offspring in. Young rabbits, too, are a source of extreme trouble. They are very small when they first commence to move about, and can get through ordinary-sized mesh netting protecting a plantation. They rapidly increase in size, and so become too big to get out, and thus start colonies of rabbits inside. For this 
reason the lower part of the mesh has had to be of small size, costing a higher price. Even at its best it is difficult, especially on rough ground, to so fix the netting, by burying it six inches in the ground and so forth, that the rabbit by dint of patient search will not find a weak spot at which he will eventually make a way through.

In the interests of the small proprietors who plant, and the country will not be able to do without the plantations which will be formed by this fairly large body of owners, it has become necessary that some authority should be set up with powers to see that the rabbit is either exterminated on areas, and in the neighbourhood of such areas, devoted to planting; or that owners wishing to maintain rabbits for sporting purposes should confine them to warrens, the warren being fenced in in such a manner as to reduce to a minimum the risk of their escaping.

HARES, both the brown and the blue, are more easily dealt with than the rabbit, as they do not burrow. They have the same dental formation, and feed in much the same way. They are therefore capable, especially when plentiful, of proving serious pests to young trees. The damage they commit is chiefly done, perhaps, at periods when snow is lying on the ground and they are driven to the trees for food. It should be quite possible by shooting to keep the hare within bounds. The operation may be slightly more difficult in the case of the blue hare on the hilly and mountainous waste lands, where there will always be considerable areas of rough high ground for them to breed in, owing to the 


\section{I28 PROTECTION OF AFFORESTED AREAS}

configuration of the ground making it a more laborious process for the men to get about in. In such areas, however, it will be essential that the hare should be kept down to reasonable numbers.

The SQUIRREL, though the fact is probably unknown to many people, can, when numerous, do great damage to coniferous trees, especially the Scots Pine. It gnaws the bark of the branches in a spiral manner, killing them and eventually completely distorting the shape of the trees and stopping their growth. In some districts woods have been completely ruined by squirrels alone. In such areas they can only be kept down by constant killing over wide areas.

\section{Protection against Bird Pests}

Amongst these pests, BLACK-GAME in some parts of the country, and those in which the largest of the afforestation schemes must be undertaken, comes a good first, and as a pest to young coniferous trees is second only to the rabbit. Black-game are not yet classed as vermin. They are still protected by the Game Laws and classed as game. A drastic change in this respect will require to be made if afforestation is to have any real chance in the parts of the country where they abound. And even with this change in their status they are likely to prove very difficult to deal with. They cannot be fenced out like rabbits, and will fly miles to young newly planted areas when green food is scarce in winter and early spring. They feed on the buds of young trees, especially the terminal bud, and trees so 
treated, in a few years develop into thick, stunted bushes. The damage which may be done to young pine and larch plantations by this bird is almost inconceivable to those who have not witnessed it at first hand. Protection can be afforded by painting the buds with various mixtures, but over large areas of planting the method would be expensive. Nothing short of the extermination of this bird, or its reduction to such numbers that the damage done will be negligible, will be of any use in the planting districts, coupled with its reduction to a minimum in other districts.

CAPERCAILzIE also damages young plants in a similar manner, but the bird is more restricted in its distribution than the Black-game, and is not so plentiful save in certain localities. It will be easier dealt with in the afforestable areas.

Grouse, though a sporting bird, may be mentioned here, but it is not of importance as a pest in forestry. It is said to have the same propensity as Black-game for feeding on the buds of young plants, but to a far smaller degree. Its importance as a source of revenue on areas with which forestry at present will have little connection, places it outside the purview of a pest.

\section{Protection against Noxious Insects}

We are still a long way from knowing the lifehistories and habits of the insects in this country which will have to be classed as dangerous pests to the forester. Our knowledge at present is to a considerable extent second-hand, based upon the life- 


\section{I30 PROTECTION OF AFFORESTED AREAS}

histories of similar pests (identical species) in Germany and France. Recent investigation work in some cases has shown that some of this second-hand information will not necessarily prove of practical working use to the forester in charge of woods in this country. A considerable amount of research work is therefore urgently necessary in this direction if we are to protect our woods from this dangerous source of attack.

But there are more pressing needs.

Owing to the haphazard methods on which the woods have been worked during the past century, there has always been plenty of material throughout the country for the more dangerous classes of pests, in which category may be placed the bark beetles, to breed in without necessarily, to the superficial view, endangering the living trees standing in the woods. During the war years we have been felling extensively in our home woods. All the material which has not been serviceable, tops, branchwood, and so forth, has been left in situ on the areas. This mass of material has served as admirable breedingplaces for the BARK BEETLE pests and for the wellknown WeEVIL (Hylobius), which causes widespread damage in young newly formed conifer plantations. Millions of these two classes of insects alone have been reared throughout the country during the past four years. Inevitably we shall have to face serious attacks from these insects in the near future, and it will be imperative that those who have charge of the afforestation schemes should bear this serious problem in mind. 
Looking further ahead, there is another point which deserves mention. It is a well-known fact that with the increase of areas of a pure crop of any kind, agricultural or forestal, takes place a like increase in the pests which feed upon it. This especially applies to forest pests, and to none more than the bark beetles, who deposit their eggs in the sappy layer beneath the outer bark. Pick up a bit of old bark in the woods. On its inner surface you will see patterns and designs as if scored out with a sharp instrument. You may see identical patterns on the outer surface of the stem from which the piece of bark has fallen. These are made by bark beetles and their grubs. If sufficiently numerous, the whole of the inner bark of the tree may be covered with these designs, and the green tree will have been killed by the hundreds of thousands of these small creatures who lived in it.

In crops of one species reproduced over considerable areas of country, you provide a large amount of food in compact blocks, thus favouring the increase of a pest addicted to feeding on this particular species. The fact that there have been no serious records of plagues of bark beetle and other pests on a large scale in Britain in the past, such as, e.g., the forests of France, Germany, and America have witnessed, by no means infers that we shall not have to face them in the future.

There is one forest insect which many are acquainted with - the little caterpillar which appears in its hosts and strips the oaks of their leaves in early summer. These attacks do not 


\section{I32 PROTECTION OF AFFORESTED AREAS}

do any good to the oak. As a matter of fact, the removal of the leaves stops the growth of the tree, the formation of wood, in the middle of the growing season, thus reducing the increment of wood put on that year. Such attacks carried out persistently on a tree over a number of years result in a smaller amount of timber being realized from that tree when it is finally felled.

From the foregoing remarks it becomes evident that some form of enactment will be necessary to enforce a common measure of protective management for the forests of the country with a view to making it imperative that all proprietors should keep their woods clean in order to minimise insect attacks. And that it should be out of the power of any proprietor, as it is not at present, to endanger the woods of his neighbour by working his own on unscientific lines.

Protection against Noxious Plants and Fungi

Beyond mentioning the fact of the existence of dangerous plant and fungus pests, such as, e.g., mistletoe, dodder, furze (whin), broom, bracken, etc., and several far more dangerous fungi, all of which in their various degrees and localities may prove inimical to the growth of trees, it is impossible to deal with this matter in any length. A great deal of research work in this direction is necessary to enable methods of practical usefulness, and at the same time not too costly, to be put in force in the forest to counteract them. A well-known instance throughout the country is the common larch canker, which may, and often does, kill out single trees or 
patches in a plantation and may even destroy the greater part of it.

The recommendations already made above for the protection of woods from infection from neighbouring areas apply to these pests.

\section{Protection against Game Animals}

There will be few possessing a knowledge of the facts who will gainsay the fact that sport as it has been carried on during the past half-century has had an adverse effect on the growth of woods as a commercial proposition. In the majority of cases the wishes of the gamekeeper have been paramount, and the forester and his management have had to take a second place. This is not to say that of necessity the woods were wrongly utilized. If the object of management of the proprietor in the growth of his woods was primarily for sporting purposes, to afford areas of retirement for breeding and rearing purposes, and in the case of pheasants high rises when the birds came to be shot, it became the duty of the men he employed to carry out these wishes. The fact, however, remains that they were detrimental to commercial forestry. In the case of deer also, the maintenance of a large head of these animals militated against the possibility of woods of any size being grown on the portion of these areas suitable for the purpose, the plantable lowlands, since they were required to provide wintering for the animals.

An afforestation scheme on any scale in the country will therefore necessitate a change to some extent in the method under which sport has been 


\section{I34 PROTECTION OF AFFORESTED AREAS}

enjoyed during the past few decades before the war. The large area devoted to deer forests in Scotland, some $3,500,000$ to $4,000,000$ acres in extent, will require to be considerably curtailed in the interests of the people of the country-side and of the nation.

DEER may be first considered. The two species which will have to be protected against are the red deer and the roe. The former spend the summer and autumn seasons up on the rough mountain sides and tops, above the elevation at which present planting is contemplated. But the winter is passed on the lower grazing-lands, on areas which fall within the prospective planting zone. The damage they are capable of committing in young plantations is very great. It would be essential to keep them out till the plantation had reached a minimum age of, roughly speaking, twenty years. And this age might have to be exceeded.

This would entail high and expensive fencing some seven feet or so in height, and where deer are kept the owner should be forced to pay for all such fencing and for its maintenance during the period required.

It will be necessary, as already mentioned, to reduce the area of existing deer forests. This latter point will not in all probability prove of such diffculty, as it is unlikely that sporting values will for a long time to come reach the figure they enjoyed before the war, and many owners are likely to be ready enough to convert some of their deer forests, or the plantable portions of them, into commercial woods, these areas having lost their former high value as deer forests. 
Roe deer are not maintained for their sporting value, but more commonly are permitted to remain on an estate for their beauty alone. They are beautiful little creatures, but amongst the most destructive of animals. They will tear the bark off young saplings, and eat the tops off young plants, in a spirit apparently of pure wantonness. The amount of damage half a dozen roe will commit in a short space of time in a locality is almost incredible.

In IgI6, in the vicinity of Edinburgh, we experienced a very open February and early part of March. Labour being short, I took advantage of an opportunity which offered of getting the work done, and had some 5,000 spruce put out in an old open wood. A heavy snowfall took place two days later, and at the end of a fortnight from the fall the greater part of the spruce had lost their tops from roe deer. Before the third week all the spruce had been so eaten down by roe deer that scarcely a score survived. Most of the damage done was wanton destruction, for very little was actually eaten. There were only three of the deer.

It is impossible to fence against roe deer. The expense of high fencing would be unjustifiable, and nothing else would be any good. They travel over considerable distances in their particular areas, and the only way to deal with them in areas to be utilized for afforestation purposes will be to shoot them down. Thedamage they commit is out of all proportion to any value they may possess, either pecuniary or artistic.

The preceding remarks are not intended to convey the idea that the sport of deer shooting must dis- 
appear from the country. It is improbable that it will ever do so. In fact, in the years following the appearance of a considerable area of forests in this country, deer, under proper control as to numbers per unit of area, will doubtless increase. In German and French forests deer exist, the number of head being strictly limited to what the forest can support without excessive harm to the trees. In fact, at times this number was exceeded in exceptional circumstances. The late King of Saxony was very fond of deer shooting. I remember, during a visit paid in I904 to the School Forest of Tharandt, in the vicinity of Dresden, I remarked to the forest officer on the apparent excessive number of deer in the forests. The officer replied that the number was maintained in the forests by order of the King; that he paid for the extra protection afforded to the trees, for the high wooden palisading erected round areas of young growth, and for feeding the deer with hay and turnips throughout the winter. The palisading cost half a mark per running metre to erect, and for the protection of the trees in the pole and middle-aged crops branches were tied round the stems to prevent the bark being rubbed by the deer when their horns were in velvet. I quote this as an illustration in point. Sport will not disappear from this country with the advent of commercial afforestation. We should all be sorry to see it disappear. But we shall have to adapt our methods of obtaining our sport to the new conditions which the national interests and the national safety imperatively demand. 
Pheasants constitute the game bird par excellence which has regulated to a great extent the management of a large area of the woods of this country.

The chief desiderata governing the sport connected with this bird are cover on the ground and high rises-i.e. belts of tall trees over which the birds may be brought at a sporting elevation above the guns. To obtain these objects the whole management of the woods in the past has been based on certain requirements, topographical ones and others. And to fulfil these objects very often the conditions required for commercial forestry have been impossible of fulfilment.

It is open to doubt whether the rearing of pheasants on the scale which it had reached at the outbreak of war will be seen for some years to come in the country. But be this as it may, the maintenance of the woods as a commercial proposition on an estate is not antagonistic with a very fair amount of pheasant shooting. But the latter must be subordinated to the former. The forester must be in control and the gamekeeper occupy the subordinate position.

The practical study I had made of this question before there was any question of the war, led me to the conclusion that it was quite feasible to prescribe a well-conceived system of management on a forest estate with a proper sequence of fellings and plantings laid down on a well-thought-out plan whilst at the same time keeping in view the main requirement of the owner, that his woods should be able to a fford him first-class pheasant shooting. Such a scheme, owing 


\section{I38 PROTECTION OF AFFORESTED AREAS}

to the haphazard way in which fellings and plantings had been carried out in the past, would take some time to introduce, and might entail or have entailed the sacrifice of woods which had not reached their full felling size. With such a series of woods, what would be the position as regards the shooting ?

Firstly, it would necessitate the keeper changing his rearing localities with the change in the areas open to him for such purposes during a series of years. Secondly, all young plantations would be closed to the keeper. Where the area was sufficiently extensive, if possible they should not be subject to being beaten through by beaters when the coverts were being shot. They could be gone through by the keeper and an assistant or so before the shooting commenced to put the birds into the open woods.

Thirdly, the young plantations would afford considerable cover and shelter to the birds.

Fourthly, as soon as the cover overhead of the middle-aged woods allowed sufficient light to penetrate to the soil below, on the understanding that the owner was prepared to spend money to obtain extra sport, a ground cover could be introduced of shade-bearing shrubs-of which an infinite varietyare now on the market; or if the woods consisted of a light-demanding species, such as the larch, they could be underplanted.

This cover would not interfere with the growth of the trees, would improve the soil conditions, and would afford protection to the birds.

Fifthly, the old woods before felling would in a varying and changing degree afford the high rises 
demanded by the sport. To afford more cover on the estate the old woods could be underplanted, and the soil would be the gainer. They would change more often than has been the case in the past, since as soon as the woods had reached the commercial felling age they would be cut out and the areas replanted. Consequently the varying position of the old woods would necessitate modifications in the system of driving the covers. But this to a proprietor who is himself interested in this aspect of the sport would present an added interest. And the same applies to the good keeper.

On the subject of the attraction a young plantation in its early youth has for pheasants, I may give an illustration culled from personal observation during the past shooting-season. I planted a small piece of larch, barely above half an acre. It is eight years old, from the seed, and growing remarkably well. The area had been felled during the war. On one side lies a stretch of arable land, on the others three old woods on the slopes of a glen, with practically no undergrowth in them on the south and western aspects. I visited the little plantation, once or twice throughout the winter. More often than not a large covey of partridges reared in some rather tall larch in the nursery, a quarter of a mile away, were to be found in the plantation, and as often pheasants in varying numbers were to be observed scratching about for food. It is needless to say that no food of any description had been put into the woods during the season. The little plantation on its own merits attracted the birds. 


\section{XI}

\section{FORESTRY EDUCATION}

THE educational side of the forestry question comes in the forefront of the whole business, since without the trained and qualificd men you cannot embark with safety on any scheme, be it large or small, as the past state of British forestry has well demonstrated.

We have all learnt from the war that Germany's great source of strength lay in the manner in which she made full use of experts, in their several special lines of work, in furthering the economic development and interests of her Empire and peoples. In the future we may hope to see the expert occupying his rightful position in the economic work of this nation. In the existing absence of knowledge on the subject of what scientific forestry aims at in this country, it is perfectly certain that it will be merely throwing money away to place this afforestation matter in the hands of any but experts. It becomes the duty, therefore, of all the forestry educational establishments in the country to set about turning out fully trained and qualified men for the various grades of a future forest service at as early a date as possible, for it will be those men who will 
be responsible for the working of the considerable afforested areas we may hope will be in existence twenty years hence.

There are good educa tional centres for this purpose in existence in various places throughout the country. It is in part due, not entirely, but to a considerable extent, to the far-sighted action of the Development Commissioners in placing the improvement of forestry education, and the appliances and buildings required for this purpose, in the forefront of their forestry schemes that the end of the war has found us so well prepared in this respect.

You will ask, how is the forestry expert trained ? It is a specialized training. We will briefly consider the training for the gazetted ranks first. At Edinburgh University the student is required to possess an education enabling him to pass the preliminary examination of the University. During his first year's work for the degree of B.Sc. in Forestry he follows courses in Botany, Zoology, Natural Philosophy, and Chemistry, receiving a solid grounding in those subjects. During his second year he takes the first part of his forestry with Forest Botany, Forest Engineering, Surveying, and Geology. A considerable amount of practical forestry work in the field is undertaken in the Easter vacation, summer session, and part of the summer vacation of this year. In his third year the student takes advanced forestry, forest chemistry, and forest zoology, the summer session being entirely devoted to the final practical course in forestry.

If he passes successfully through this curriculum 
during which he will have done some six to seven months' practical work in the woods, he will graduate as a B.Sc. in Forestry.

This was the position up to the summer session of IgI8. It had been recognized, however, that it would not be possible to ask men who have been fighting for their country during this war, having left 'varsity or school for the purpose, and who wished to subsequently follow the career of forestry, to spend three years in taking the degree. The University therefore decided to introduce a diploma in forestry for all men who have served in H.M Forces, the diploma to be obtainable in two years. Men who are eligible are therefore excused the preliminary examination and a portion of the first Science subjects, thus enabling them to qualify as fully trained forest officers in two years. The most careful consideration was given to the curriculum to be followed, it being recognized that two years was the absolute minimum in which a candidate for a post in the higher executive grades of a Forest Service could be adequately trained.

As evidence that this policy was meeting a national requirement, a considerable number of officers, some discharged from the Army, others on medical certificate, commenced this diploma course. Further, in compliance with an inquiry from the Kitchener Memorial Scholarship Fund for Oversea Members of the fighting forces as to whether the University would undertake to give a year's forestry training to selected men, the University Court instituted a Certificate in Forestry to be granted to 
individuals deputed to the University by the organizers of this fund, provided they fulfil the qualifying requirements.

I think, therefore, that in this important matter of training fully qualified men in forestry, Edinburgh (and other centres, Oxford, Cambridge, and elsewhere, are similarly engaged) has kept well up with the needs of the country, and in this respect fulfilled the promise which her action in instituting the first lectureship in Forestry in this country as far back as I888 would lead the public to expect from her.

It has been said that the mere taking of a degree or diploma does not make a forester. That is true: but so is the converse. The mere practice of forestry in the woods without a sound scientific training in the theory of the subject does not produce a forester capable of correctly managing commercial woods, as British forestry in the past has well exemplified. The same argument applies to training in agriculture or banking, and every other profession for that matter. You may pass with honours in courses in banking, but no bank manager would consider you competent to manage a bank or even assume an important position in the bank.

The young forester armed with his degree or diploma must now go to the woods to obtain the practical experience which will one day make him a qualified and capable expert. As an assistant to a qualified officer he will, whilst picking up this experience, be earning his living and prove of considerable use. That this is the case is exemplified 
by the fact that all the available students who graduated immediately prior to or during the war were utilized by the Timber Supply Department for special work.

For the training of the lower executive grades, courses in the Agricultural Colleges and Woodmen's Schools exist. The Agricultural Colleges provide courses in forestry and allied subjects on the standard required by non-commissioned ranks, foresters, and senior woodmen. For the lower ranks of woodmen, thanks to the energetic action taken by the respective Boards of Agriculture, three schools are now in existence-one each in England, Ireland, and Scotland. The English school is situated in the Forest of Dean, and has been in existence for the last decade and a half. The Irish one was formed several years ago ; whilst the Scottish one at Birnam in Perthshire was opened last year. At these schools the theoretical work in the class-room is combined with the ordinary work of woodmen carried out by the students in the woods, for which they are paid. The purely class-room work is also illustrated by practical demonstrations in the woods. The course is usually a two-year one, and is so designed that students who show promise and reach an educational standard enabling them to profit by the higher courses may ultimately proceed to the agricultural and university forestry centres.

The existing Woodmen's Schools will require to be supplemented by others situated in parts of the country where blocks of woods of a sufficient area still remain standing. 
Thus the educational facilities now in force, as is intended, enable a brilliant man to aspire to reach the highest posts in a forestry service.

I have alluded to the practical portion of the University education in forestry. It is a highly important part of the business. It is impossible to teach forestry entirely in the class-room. A few words are therefore necessary on this subject.

To give this training effectively, you require to have:

(a) A small area of woods with a good forest nursery.

(b) A much larger area of woods which we have come to term a demonstration area.

(a) The small area, or Forest Garden as it has been termed.-This small area, I00 to 200 acres will suffice, with its forest nursery, is required primarily for the preliminary practical work of the forest student. In it he will actually learn to perform the manual work of the forest labourer. For unless he learns how to do this himself, he will never be in a position to superintend his labour force efficiently in the future. In this area he will make full acquaintance with the methods of raising young plants and of planting them out in the woods, and will undertake a variety of other work which it is unnecessary to detail at length here. In the area small experimental plots of various species will be grown, and use be made of the small areas of old woods the area should possess for technical work of other kinds. Most of the forestry educational 
centres, including Edinburgh, now possess an area of this nature.

(b) The Demonstration Area.-This area must be far larger than the small one, comprising several thousand acres managed on the best principles of scientific forestry.

The Development Commissioners have given considerable attention to the acquisition of demonstration areas for the use of the training centres in England and Scotland. An English demonstration area is in existence, comprising the Forest of Dean and neighbouring High Meadow Woods. This is an excellent area in which the Scottish student can study conditions not obtainable in the north. We have used it during the four war years with, I think I may say, excellent results. Since the Forest of Dean belongs to the Crown, its acquisition for the purpose required was comparatively easy. Unfortunately a demonstration area has not yet been settled upon in Scotland, but we may hope that this will be one of the first pieces of work put through after the peace settlement.

The Demonstration Area is required for the practical work of the advanced students, where a mongst other work they prepare what we term a working plan-that is, a plan which prescribes, for a period of years, every piece of work, including fellings, plantings, tending of the woods, their protection, export works to be inaugurated, and so forth, which has to be carried out in the area during the period. It is a highly technical piece of work.

The Demonstration Area is also required for re- 
search work in forestry. This work, to which I have already briefly alluded, is of such a manifold nature that it is impossible to go into the matter here. I may say, however, that research is very badly needed if British forestry is to one day rank as second to none in Europe. And we all confidently expect it to take this place.

In the past and at the present time the educational forestry centres have been indebted for the opportunities of undertaking these courses of practical training to the kindness of private proprietors throughout the country. It is impossible to speak with too great warmth on the value of the assistance thus accorded, or of the assistance and cordiality with which they and their agents and foresters have invariably given to and shown the students. It is another direction in which the nation is indebted to owners of woods, for many of the students so trained have gone out to serve in the Government forest services of the Empire, in India and the Colonies.

Even with the formation of the necessary demonstration areas, the training centres for some period to come will still require their students to visit areas of privately owned woods. This fact provides another reason, to those given in a subsequent article, for the advisability of aiding proprietors to reafforest the areas on their estates felled during the war. 


\section{XII}

STATE OWNED VERSUS PRIVATELY OWNED FORESTS

THE brief survey made of the history of the forests of this country will have shown that we have no state forests in Great Britain if we omit the areas acquired within the last decade in Ireland. The only woods not privately owned in Britain are the Crown woods, such as the Forest of Dean, New Forest, and so forth.

On the continent of Europe the State in a varying degree possesses a certain proportion of the forests of the country. In France, for instance, the State owns I $2 \%$ of the forests, $20 \%$ are communal forests, under State management, and the remainder are private forests. In Russia the major part of the enormous forest area in the country belongs to the State, including, since the abdication of the Romanoffs, the very extensive Appanage, or Imperial forests.

In this country, then, this question of afforestation starts from the basis of an entire absence of Stateowned woods or land capable of growing commercial forests. The land is practically all privately owned, and is so tied up in a variety of ways as to render its acquisition by purchase a difficult and expensive business under the existing laws. 
With this position to face then, the question as to whether it is more advantageous for a nation that the State should own the forests of the country or a percentage of them, or whether the industry can be left entirely to private enterprise, requires consideration.

We have seen that in the past private enterprise did not succeed in providing the country with an area of commercial forests at all commensurate with its requirements. But the war has taught us all our lesson in this respect.

Let us glance at some of the advantages of Stateowned forests as contrasted with private ownership.

The management of State-owned forests is usually carried out on the principle of a sustained yield from the areas in order that the requirements of the people and industries may be supplied. The State is also able to grow large-sized timber required for special purposes which takes a long period of years, I50 to 200 , to produce. On the principle that the State goes on for ever, it can afford to await the return on the capital invested to produce this class of material. Thus in these respects the interests of the State and the people are identical.

The private owner, on the other hand, is more interested in obtaining the greatest profit from his area in the shortest space of time, and to obtain this he may wish to grow the smaller classes of material demanded by some of the markets. When in need of money there is nothing to prevent him felling his woods, perhaps cutting some at an age below that which is the most favourable one in the 


\section{I5O THE STATE AND PRIVATE FORESTS}

general interests of the community. The private owner is not in a position to wait the long periods necessary for the growth of large-sized timber, the production of a certain quantity of which may be essential to certain industries in the country.

The State can afford to accept a smaller rate of interest on the capital invested in its forest property than would be possible for the private owner. This is admissible in the case of the State, since it reaps indirect advantages by the provision of material necessary to the industries of its people, in the appearance of new industries dependent on the materials of the forests, by providing work for a portion of the population, thereby raising the standard of comfort of its people, and so forth. These are undoubted advantages to the State, but cannot be regarded from the same view-point by the private owner.

Commercial forestry to be successful requires to be carried out in compact blocks of land, involving a considerable amount of capital, and the larger the area, within reason, the greater will be the success of the operations, since it is possible to maintain better transport facilities at a smaller cost per unit of area. And the large areas of forest provide a greater annual amount of material by which industries using this material can be inaugurated and maintained, providing work for a considerable head of population.

The private owner is not usually in a position to provide and maintain large compact areas of forest, though this would, in some cases, be possible if a 
number of owners combined to manage their forest lands, when more or less contiguous, on this principle.

State forests are also of value in producing an annual income from a source other than the pockets of the people. They also enable the State in periods of stress to obtain an extra income by making additional fellings. And also, as the war has shown, provide a reserve of material which may become of the highest importance to the nation in time of war.

The latter point has been illustrated in the strongest manner by France and Great Britain during the past four years. France has had to sacrifice many of her fine forests, but she has still a great reserve left. And the timber she has been using has been of good quality, whilst that of Great Britain has been inferior. Nor has France, in this respect, had to experience during the last four years the trouble and anxiety which have faced our Government in this matter.

The possession of forests by the State enhances its credit and prevents the accumulation of the land in the hands of comparatively few of the population. And finally, a point which was considered of considerable importance in some continental countries, provided the State owns the minimum area of forests commensurate with the security of the country's supplies in periods of stress, it was held that it would be unnecessary for the Sta te to interfere with the management of the privately owned forests of the country. 


\section{I53 THE STATE AND PRIVATE FORESTS}

The chief arguments which used to be advanced against the State ownership of forest property were the undesirability of State interference or competition with the industrial undertakings of the people, the inadvisability of the State entering into competition in the open market with private individuals in the sale of its timber, and the fact that the laws made for the protection of the forests of a country were made by the State-i.e. in the interests of part of its own property. And finally it was held that the State could not manage forest property as profitably as the private individual.

These being the pros and cons of the ownership of forest property, their application to the position in this country may be considered.

All the land which is required for the afforestation schemes is owned by private individuals, and of corporations, water trusts, and so forth.

Moreover, under the existing law the delays in acquiring by purchase any considerable areas of this land would be incalculable and the price prohibitive. All who have any acquaintance with the land, and the difficulties encompassing a change of ownership, must recognize the impossibility of any progress being made under the old methods. The chief delay has always centred round the title decds. These are made over to a lawyer, who considers it his business to endeavour to find holes in them. Months go by before the land is actually transferred at the expenditurc of a considerable sum of money. The land required urgently for agriculture, small holdings, and afforestation can never be obtained in this 
manner. It is wanted at once. This, in a few words, is the position accepted by all who have studied the question.

It may perhaps be granted at once that some alteration in the law to facilitate the more speedy acquisition of land, both for agriculture and forestry requirements for well-defined public purposes, in the interests of the community, will be introduced. A Committee has been sitting and has made suggestions on this head.

The State will, we may infer, be armed with some form of power for the compulsory acquisition of land for well ascertained public purposes.

But the existence of such a law by no means presupposes that the land required for afforestation, save perhaps in exceptional cases, will be obtained through the enforcement of these powers. Nor is it by any means certain that it would be desirable that the afforestation of the waste lands in this country should proceed by the way of State ownership. The basis of our land occupancy is unlike in many ways that existing in any continental states.

It will, I think, be held by most people that a man has as much right to his land as other sections of the community to their houses and other property - to their stocks and shares or War Loan-provided the land is put to its best uses in the economic interests of the community.

Moreover, the proprietors of the land which it is desired to afforest have played a not unimportant part in the carrying on of the war. Their woods may not have been all that was desirable in their 
I54 THE STATE AND PRIVATE FORESTS

method of growth and so forth, but still they have served their purpose. They had been grown at great cost, an extravagant cost, but their owners had borne this cost. When called upon, they offered them to the country willingly, although in many instances the sacrifice has caused a severe wrench. Never again for them will their homes and land be quite the same, with the landmarks with which they grew up from childhood gone for ever. In many cases it is a bare and destroyed country-side they will have to pass the rest of their lives in.

For this reason, and there are weightier ones from the national standpoint, it would be almost an injustice to deprive a proprietor of the ownership of his land if another way out can be found. For instance, it would be an injustice to take from an owner such part of his estate as could be afforested at present-i.c. the best of the winter grazing-landleaving him with the balance consisting of arable land and poorer, high rough ground, the latter, with the winter grazing gone, being almost valueless. The value of the estate would be considerably depreciated in this way. It would be necessary in fairness to take over arable, plantable and unplantable land, and the cost involved would be prohibitive.

From the national standpoint, in face of the gigantic debt which we have incurred, and from the financial aspect as it bears on the creation of the new forests, the cost of purchasing the land required for afforestation on any considerable scale is practically out of the question. 
The State ownership of forests in this country on any considerable scale may then be ruled out of the question. But the State should assist by owning small areas; and especially is this necessary to give the lead in the growth of hard woods such as, e.g., oak, which requires a long period of years to produce large, high-quality timber.

What is the land we shall have to make use of in the afforestation scheme?

And how is the land to be acquired?

The answer to the first question is that, broadly speaking, the greater part of the land is at present utilized in three ways: (I) As deer forests ; (2) Land used chiefly for sport, exclusive of deer forests : (3) The area of so-called mountain and heath land used for grazing purposes, chiefly sheep grazing.

The area of land devoted to deer forests at the outbreak of war was somewhere in the neighbourhood of 4,000,000 acres. The total mountain and heath land was put at some $I 6,000,000$ acres.

Much of this area is above the present limit of afforestation. Perhaps it is safe to say that some $5,000,000$ acres are capable of being planted up without excessive cost being incurred in the operation.

Both deer forests (though perhaps to a lesser extent than before the war, owing to their greatly depreciated value) and grazing lands present the same problem for solution. They both consist of lower ground necessary for the wintering-i.e. the winter grazing and protection of the deer and stock during the inclement season of the year-and the II 
I56 THE STATE AND PRIVATE FORESTS

much larger area of rough highlands used for summer grazing.

The afforestation schemes propose to utilize the lower or wintering ground. But if all this land is afforested, the high summer grazing-grounds become practically valueless.

This is one of the main problens facing this afforestation question, and which practically puts out of court State purchase of land on any considerable scale. Once you have your woods up and old enough to permit sheep grazing, the problem becomes easier, because it will be possible to permit such animals as sheep to graze and winter in the woods in the cases where the species grown allow sufficient light to penetrate on to the soil to permit the growth of grass.

But the interval whilst the woods are being grown is the period which demands the most careful thought and treatment at present.

Some form of leasing will, it is suggested, be the best way of solving the problem, as it will permit of the areas selected being taken up gradually and only as required, and will thus cause a minimum of dislocation to vested interests.

That some dislocation is inevitable is unfortunately unavoidable, and compensation will have to be paid for the disturbance. The compensation for the dispersal of acclimatized sheep is far heavier than would have to be paid for sheep in low-lying, sheltered areas, where no heavy losses in the acclimatization have to be incurred by the sheep farmer. On the other hand, when the sheep are reintroduced 


\section{AN UNPROVED INDUSTRY}

into these areas, once the woods are old enough, acclimatization losses will not have to be faced, since the shelter which the woods will bring should reduce the losses from exposure to a minimum.

And now as to the second question-the acquisition of the land.

State ownership on any considerable scale may be concluded under existing circumstances as unpracticable. But this does not rule out the State altogether in this respect. It is an accepted economic principle that the State in the interests of its people should demonstrate the economic and pecuniary advantages to be obtained by the introduction of a new industry into the country.

Commercial forestry is an industry the financial advantages of which are as yet unproved under existing conditions in Great Britain. It would therefore not only be a direct advantage, but becomes a duty, for the State to set the example to private owners by demonstrating beyond a doubt that the industry can be made a paying one. For this purpose the State should acquire by purchase a certain area of land in different parts of the country, possessing varying capacities, and so capable of growing on a commercially profitable basis the different species of trees for which there exists a demand, both conifers and hard woods. By this means the paying capabilities of the different species, and the ages at which, from the private owner's point of view, they could be most profitably cut, would become demonstrable, and the State would ultimately be in a position to judge the crops it could 


\section{I58 THE STATE AND PRIVATE FORESTS}

most profitably leave to private enterprise and those to which it should confine its own operations. For instance, as an illustration in point, from the statistics which have been obtained during the war by the measurements of crops cut over for war purposes and others, it has been demonstrated that the growth of larch and other species is far more rapid on the West Coast, from Devonshire, through Wales, far up into Scotland, than on the East Coast. This, with the proximity of the Gulf Stream on the West is understandable. But it has also been ascertained that in some cases existing crops measured show a much greater approximation to normal crops than was anticipated. In fact, it may be taken as fairly certain that in the West pit wood and crops of timber size will be produced at an age below, and in some cases considerably below, what obtains in Germany, and it is considered probable will carry per acre heavier crops than the German statistics reveal for that country. In fact, it appears highly probable that the fears that forestry will not prove a paying proposition are, for some areas in the country, unfounded. Rather that the reverse may be looked for.

A government lead in the matter, therefore, whilst being a duty, may, it is hoped, prove a paying investment of the nation's money. Private enterprise will not be slow to follow such a lead once it has been demonstrated that commercial forestry is not a leap-in-the-dark business.

But the area which the State might acquire for the purposes of demonstrating the value of com- 
mercial forestry can only be a comparatively small proportion of the land it is desirable should be afforested. The State's duty with reference to the remaining areas where afforestation is urgent should proceed by way of the supervision by properly trained forest officers of the newly planted tracts, once they have been planted with State assistance. And the acquisition of the land for planting will probably be best accomplished by leasing the land required.

The leasing system offers several advantages both to State and owner. The State is not burdened at a heavy cost with considerable areas of land which it would be impossible to afforest all at once, and part of which it may be impossible to plant up for a long period of years. The owner retains possession of his land, which is only taken up as required, and when acquired enjoys the advantages of an ordinary lease. The ownership remains the same throughout, without the very often resultant upheaval which follows the transfer of land to a new purchaser.

The leasing method has been under consideration for the past eight years by the Development Commissions and Boards of Agriculture, and some instances of the acceptance of offers of this nature are already in actual practice. But for the incidence of the war they would be far more abundant.

The leasing system may be by way of an ordinary lease under which the lessee enjoys full ownership of the land for a period of years or by a proceedssharing lease. In this latter the owner forgoes his rental, bears a share in the maintenance of the 


\section{I60 THE STATE AND PRIVATE FORESTS}

plantations, and the State pays the cost of afforesting the area; the proceeds of the crops are then divided between the owner and the State in a proportion depending upon the part each has taken in the initial and subsequent outlay. The owner thus maintains throughout a direct interest in both land and crop. For proprietors who are able to forgo the rent they were receiving for the land, this is undoubtedly the best system. The owner of the land has another advantage under the leasing system, in that he eventually receives full control of his land, whose value by then will have considerably increased.

There remains for consideration the areas felled over during the war. It may be admitted that proprietors of woods have received a price for their timber out of all proportion to its pre-war value. A proportion of it was unsaleable before the war.

For various reasons, chiefly the labour one, it has remained unplanted. Had the War Office permitted the employment of German prisoners much earlier in the war years than was the case, a good deal of the replanting of some of these areas might have been undertaken, and some proprietors would have been glad to have devoted a portion of the sums received for their timber to this purpose. Little has been done in this connection. The war dragged on, and probably but a small proportion of proprietors are now in a financial pcsition which will enable them, however willing, to expend considerable sums on replanting their felled-over areas.

In the interests of the country it is, however, of 
urgent importance that these areas should be replanted in all cases save where the land can be put to better purposes.

There would therefore appear to be a strong case in favour of the State assisting, by loans or grants and with the necessary safeguards, the owners of such areas, in order that this replanting should be proceeded with at the earliest possible moment. From the records of measurements instituted by the HomeGrown Timber Committee, and continued by the Timber Supply Department, we know the capacity of these lands for tree growth. We have ascertained data to go on, which is not the case with the derelict areas. It becomes obvious therefore that their reafforestation should not be delayed. It has been shown that the owners have patriotically sacrificed their woods to the nation's needs, even in cases where the pecuniary returns received were of no great moment to them.

If, then, it can be shown that it is to the interest of the public welfare that these areas should be reafforested as an urgent necessity to the country, and there can be little doubt on this head, it would appear that a case for assistance to the owner exists whenever the owner can show that the war has not left him in a position to undertake the work solely from his own resources. Certain safeguards will be necessary to ensure that the woods so formed are properly managed, but it would be to the interest of the owner to accept such supervision. 


\section{XIII}

\section{THE AFFORESTATION SCHEMES}

WE have now arrived at the main point to which the previous chapters have been leading up-the afforestation scheme itself.

Given that it is admitted, and it has been so admitted by the Government, that the afforestation of a portion of the waste lands of the country is now recognized to have become a national necessity, the chief question for consideration is the scale and method by which the business should be carried out. In this connection it is necessary to bear in mind the objects, or the main objects, which the scheme is desired to fulfil. These objects, as has been shown, have an intimate connection with the social and economic conditions of the population in parts of the country and with national industries.

In the recommendations of the Forestry SubCommittee, appointed by the Reconstruction Committee, which will be referred to later, the main object kept in view, with reference to the areas recommended for afforestation, was the national safety margin. In other words, that we should plant an area sufficient to provide us with timber and pit wood to cover a three years' war period. This 
Report was drawn up during the war, under the influences of a period when the timber difficulties, as has been already mentioned, were causing us the most serious anxiety. The Report bears the imprint of the war pressure upon its pages. In the minds of all acquainted with the position, the war needs of the country loomed large, and were, as was inevitable at the time, given a prominent position, a more prominent position than is perhaps now necessary, in the issues before the country.

The war is over, and the Peace Conference are engaged in discussing the League of Nations. If we are to take these discussions as being carried on in good faith, and as having a real intention of making an effort to put an end to war, and there are but few who have any doubts on this head, we can no longer appeal for the support of the public in this afforestation matter, giving as our main argument the national safety point of view.

We have seen that this business, if carried out with judgment and on a large enough scale, may be made to improve the social conditions of the rural population; that it will increase the numbers of that population in the at present sparsely populated areas of the country; will give rise to flourishing industries, affording work to a considerable future population; and should result in the saving of large sums of money leaving the country in payment for timber imports.

It may be suggested that this would be a more favourable basis from which to appeal for the support of the country, and from which to consider 


\section{I64}

THE AFFORESTATION SCHEMES

the scale upon which the operations should be carried out, since the policy to be adopted and the advantages to be gained would be better appreciated by the public.

Then we have the future timber supply question. I have dealt with the next forty years. But in timber matters we have to look further ahead than that comparatively short period. It takes seventy years or so to grow even coniferous timber. Under the stress of war we had to get the material we required, no matter what its price, and we were made to pay for it. In I9I5 and I9I6 we threw away in this fashion $£ 37,000,000$ more than its prewar value for the timber we imported. This sum would have paid for a very fine afforestation scheme if spent from I 885 onwards.

And in the days to come, in the absence of the virgin forests we have been drawing our supplies from in the past, which will have been cut out, we shall have to import planted or naturally regenerated timber grown by man and pay the extra charges asked for it. We shall be throwing away larger sums of money then.

On the subject of the expenditure to be incurred in planting schemes, Sir Alfred Ewing, Vice-Chancellor of Edinburgh University, in introducing the lecturer at the inaugural address delivered to the torestry students of the University in October I9I8, made the following apposite remark:

"We are fighting this war and spending all this money in the interests of our posterity. We should face the expenditure on this afforestation question in the same spirit." 
I have alluded to the Coast Erosion and Afforesta tion Commission appointed in Igo6, its report being issued in Ig09. The Commission examined a host of witnesses and practically every forestry expert in the country. As a result it recommended the afforestation of $9,000,000$ acres in the country. The remarkable relation existing between the acreage recommended for afforestation by the Commission and the imports of coniferous timber in IgI3 (the last year of ordinary imports before the war) is worthy of note. In I9I3 we imported $620,000,000$ cubic feet of coniferous timber, or, at 70 cubic feet to the acre (the yield which may be expected from properly managed coniferous forests), just the amount which 9,000,000 acres of forest would provide. Even this area would make no allowance for increasing imports in the future. And yet the imports of forest produce into Great Britain increased to the value of $£$ I $3,000,000$ between I909 and IgI3. This subsequent rise of itself would seem to have justified the recommendations of the Coast Erosion Commission, based as they were on the evidence of all the experts. The forestry recommendations of this Commission were to some extent belittled owing to their suggestion that the afforestation work would solve the unemployed difficulty, at the time a serious problem. This solution was ridiculed, it being said that men unused to work on the soil could not be trained and would not stand the exposure. Since then the war has demonstrated the fallacy of this argument. The exposure in the trenches has been a far severer ordeal than planting on the most 
exposed hillside in the early spring, followed as it would be by the return to a warm house and dry clothes. And the townsman has learnt to use a spade and pick with as much facility as the countryside expert. It has also been proved during the war that women can undertake planting work on all but the rougher ground.

The Report of the Forestry Sub-Committee, influenced by war conditions, as already mentioned, recommended the afforestation of an area of $I, 770,000$ acres only on the basis that this area will provide a three-year reserve supply for a future war-i.e. the national safety basis. The Committee took no evidence, which minimises the value of its report, in spite of the explanation offered that it had access to all the information and evidence on the matter. We may conclude, therefore, that it was conversant with the report of the Erosion Commission. In fact some of its members had given evidence before that Commission.

It becomes difficult, therefore, to account, save for the above-mentioned reason, for the great disparity between the recommendations-from 9,000,000 acres to under 2,000,000. Whether we shall ever be able to work up to the $9,000,000$ acres of forest in this country is beside the present question. It will be a matter for the consideration of our children and grandchildren, who will by then be in possession of the full facts as to the profits to be derived from commercial forestry in the country, and will know more about future prices of timber than we ever shall. But the point which requires, it may be 
suggested, further consideration, is whether the I,770,000 acres suggested fully meets with the requirements of the future. Whether it will enable us to have a definite hold on the markets. Whether it will really result in solid advantages to the rural districts; whether it will save to any appreciable extent the large sums of money we shall have to pay for dearer imports. Whether forty years hence we shall not find ourselves forced to throw away other $£ 37,000,000$ and more to pay for the import of timber from forests under systematic management which is all the market will then be supplying. Whether, in fact, so small a scheme, worked on its own merits, is worth the outlay and trouble it will cause, considering the comparatively small amounts of timber it will ensure to the country, and the comparatively small head of population it will affect. The Forestry Sub-Committee obtained their area as follows :-Allowing for three years' (the estimated war period) emergency fellings, during which five times the normal yield would be cut without absolutely ruining the forests, one-fifth of the area which would give us our I9I3 import figure (i.e. 9,000,000 acres) was taken, or $I, 770,000$ acres to be afforested. For hard woods, which on an average produce about 35 cubic feet to the acre, and require a better soil to grow in, the same method of calculation gives us I00,000 acres as the area required. Important as this latter crop is, and necessary as it-will be to maintain an adequate area of some of our finer hard woods in the country, this problem is not so serious as that of the conifer woods, which form the 
larger part of our requirements. Moreover, many landowners will probably continue to grow crops of this nature as heretofore, provided the State assists them with the replanting of the felled areas, and sets them the example by acquiring land and maintaining such Crown forests of this nature as have existed up to date, for instance, the Forest of Dean, and so on.

The Forestry Sub-Committee recommended that the area of $I, 770,000$ acres should be planted in a period of eighty years, at a total cost of $£$ I $5,000,000$. During the first ten years 250,000 acres are to be dealt with at an estimated cost of $£ 2,872,500$. As regards obtaining the land, they recommend that 50,000 acres should be bought, I00,000 leased, 25,000 dealt with on the proceeds-sharing plan, 25,000 acres afforested by Local Bodies and private persons, and 50,000 acres to be replanted.

Compulsion should be made possible for the acquisition of the land when necessary, in the case of the waste lands, but should not be employed in the case of felled areas when the proprietor can prove that the land is to be put to better use than for forestry purposes.

The rate of planting would depend on various circumstances-from 3,300 acres in the first year to 30,000 in the tenth year-but might be increased to provide labour for demobilised soldiers if necessary. It would admittedly be difficult to draw up a plan of operations for any long period, since the data a vailable on the subject of cost, labour, areas to be acquired, and so on are all in a state of flux at present. As, however, the plants must be grown 
to enable the planting to be done, and it takes from three to four years to grow them, it becomes necessary to fix upon the area it is possible to undertake during the first period of ten years. The Committee have adopted the correct policy in drawing up their planting recommendations for this period only.

This is the planting plan before the country which has been provisionally accepted by the Government, and will come up for final decision in the present House of Commons.

Will this scheme give you the advantages which should be reaped from the afforestation of the waste lands in the country? Will it satisfy the needs of the nation eighty years hence? And can it have anything like a decisive effect on the rural life of the large areas of sparsely populated districts in the country? Is the plan at all commensurate with the possibilities, which could be made practical realities in so wealthy a colintry as Britain? If we contrast it with the expenditure on forestry undertakings in the past in small European countries, such as Belgium, for instance, is the contrast in our favour? Answers are required to these questions before we commit ourselves to an afforestation scheme upon which great hopes are based-hopes which may not be realized.

The position of a critic is always an unenviable one unless he can support his criticisms with some alternative or supplementary suggestion which at least merits consideration.

I propose, therefore, to offer a supplementary suggestion on this matter of an afforestation scheme, 
which in my view would not only be more worthy of this country, but would produce those results which it is the desire of all interested in this matter from the national standpoint to see attained.

It will be seen that the recommendations made sta te definitely the areas to be treated in the different categories during the first ten years-to wit, 50,000 acres to be bought by the State, roo,000 acres leased, 25,000 acres on the profit-sharing basis, 25,000 acres afforested by local bodies and private persons, and 50,000 acres to be replanted. It may be suggested that it is unnecessary to lay down any rigid area limit in these various categories-e.g. there would be no object in restricting the area afforested under the proceeds-sharing basis to a quarter of that obtained under the leasing method. With reference to the area to be replanted, 50,000 acres, it appears to be far below what should be attempted. Good sylviculture prescribes the replanting of felled-over areas immediately, or after the lapse of as short a space of time as possible, in order to ensure the full utilization of the valuable humus layer which has been built up throughout the life of the crop of trees just removed. This layer forms the manure of the forest. By leaving areas unplanted for a period of years, not only is this valuable humus layer dissipated under the influence of heat, moisture, and wind, but a dense growth of weeds occupies the unplanted area, causing extra expense and trouble in replanting. ${ }^{1}$ It is as yet difficult to give an exact

1 The reasons for leaving felled tracts unplanted in Britain (Hylobius, etc.) have been already alluded to. 
figure of the area (coniferous woods are only in question) which has been felled over during the war, but it must run to several hundred thousand acres.

Now all good foresters recognize one planting rule -to wit, that all deaths in young newly formed plantations should be filled up with fresh plants before new plantation work is carried out on the estate. There does not appear to be much difference between filling up existing plantations before embarking on new planting work and replanting the felled areas, of whose capacity for producing certain tree crops we have full data, before commencing the new afforestation schemes. I would not be understood to mean that no new planting work should be carried out untilall the felled-over areas had been replanted; but I would definitely arrange for their replanting within a specified period. And having settled this important matter, I would proceed with the larger business.

With this point out of the way, we may now consider the question of the total area to be afforested. It has been suggested, for reasons already deduced, that $I, 770,000$ acres appear somewhat small.

We have seen that in I9I 3 we imported $620,000,000$ cubic feet of coniferous timber, and that our imports had been steadily rising over a period of years. There appears to be no adequate reason for believing that we have yet attained a maximum limit in our utilization of timber. Rather, with the inauguration of new industries, such as, e.g., the aeroplane industry, that the reverse may be expected. Forty years hence it is not perhaps placing the figure too 
high if it is suggested that our timber requirements, i.e. imports, may have risen by $30 \%$. This would mean an import of $800,000,000$ cubic feet of coniferous timber.

With this figure as the lowest estimate of our probable imports forty years hence, and it is, it is to be feared, below the mark, what proportion of it should we endeavour to produce at home in order to obtain the desired advantages from undertaking this afforestation business?

If it is wished to obtain from home resources a fourth of the $800,000,000$ cubic feet, you would have to a fforest an area of $2,858,000$, say $3,000,000$, acres. If it were decided that the wisest policy and the soundest, in order to assure the end in view being attained in all its various bearings, would be to aim at growing a third of this a mount, you would require to afforest an area of 3,800,000, say 4,000,000, acres ; and for half of the amount $5,700,000$, say $5,500,000$, acres.

Then as regards the rate of planting. The SubCommittee recommends 250,000 acres during the first ten years. It may be suggested that if one of the objects is to reduce at as early a date as possible the sums we have to pay for imported timber, which are likely to increase instead of decreasing in the future-and this should be one of the objects kept in view-we should aim at afforesting double this area in the first ten years. If an adequate wage is offered, and the work made attrac. tive, the country will get the men from those, both officer and man, who have been fighting during the 


\section{ESTIMATE OF COST}

past four years. And by providing this employment the nation will obtain a present return on some of the capital expended ; for it will be showing a meed of its appreciation for the men who have fought for it.

A further point. How is the land to be selected? In what order and where? The start should present no difficulties so far as the actual selection is concerned. Its mode of acquisition has been already dealt with. The country has been divided up into sections, each containing a block of counties, and each section has a forestry adviser. These officers have been at work for several years, and should be acquainted with the best land in their several areas. It will be necessary to supplement the forestry advisers in an early future by adding to the number of officers in the field, as men become trained and available. The main work will be in the field. Therefore the main staff should be a field one, and that of the office should be kept down to the absolute minimum required to carry on the work. For some years to come it will be all outgoings. There will be no receipts from the newly formed woods, and therefore no necessity for a large clerical establishment.

You will ask, What is the cost of the undertaking to be ? You have the estimated figure of the SubCommittee's report $-£ I 5,000,000$ for the whole scheme of $1,770,000$ acres, $£ 2,872,500$ for the suggested 250,000 acres during the first ten years. But these figures, and any others which could be given, are at the present moment purely theoretical ones; and the Sub-Committee's figures are pre-war ones. 


\section{I74 THE AFFORESTATION SCHEMES}

The point for decision at the moment is whether the country intends to make an endeavour, a quite possible endeavour, to get itself out of its present state of total dependence on the foreigner for its timber supplies; to create a new and important national industry, and to put to a national use its waste lands, and in doing this create work and produce decent homes for a section of the population who will prove an increased asset of great value to the nation.

The decision upon this point is of far greater moment than the question of the cost of the undertaking. No questions of cost were asked when we had to throw away $f 37,000,000$ on the purchase at exorbitant prices of timber with which to carry on the war. If we fought and won the war in the interests of our children and grandchildren, in their interests likewise we should endea vour to place them in a position of less dependence in this timber matter. For the assumed security, ill-founded as we have discovered, of our forefathers in this matter we have had to pay the price, and shall have to continue to pay for some time to come. But the sooner we make up our minds to undertake an afforestation scheme which in its several aspects shall be adjusted to fulfil to the maximum the objects desired, so much the sooner will subsequent generations reap the benefit of our prudence and foresight. 


\section{XIV}

SUMMARY OF CONCLUSIONS

IN the foregoing pages we have reviewed the history of forestry in this country since the days of the Roman occupation. We have seen that between the sixteen th and eighteenth centuries the old science of British Forestry had its origin, reached the zenith of its utility to the nation, and, for various economic reasons, declined, until by the beginning of the nineteenth century it ceased to be a factor of any importance in the life of the nation. That during the period in which its importance was fully realized it was fostered by the Government of the day, both for the material produced, which was utilized by the population, and for the high-class timber it was necessary to grow to provide for naval requirements.

We have seen that there was a great planting revival in the early years of the reign of Charles II, inaugurated by John Evelyn, well known at the period as a member of the Council of the Royal Society, the campaign being initiated owing to the increasing shortage in the supplies of timber required by the Admiralty. It has been shown that the command of the seas, assured in the early part of the nineteenth century, the change in materials 
introduced in the construction of ships, the increased facilities in transport and communication, the removal of the import duty on colonial and foreign timber, and the change in the kind and classes of timber used in construction, etc., brought about the gradual decrease in the amounts of home-grown timber used, and consequently in replanting, and resulted in the decline of British forestry as a commercial undertaking.

The latter quarter of the nineteenth century witnessed a slight revival in British forestry, a few enthusiasts, chiefly landowners, endeavouring to enlist the sympathy of the Governments of the day in replanting schemes and introducing into the country scientific forestry education on Continental lines.

It has been shown that the Government appointed Committees and Commissions during this period anc' in the first decade of the twentieth century, but that, with the exception of some slight improvement in forestry education, no real progress was made in afforestation proper. Not a single tree was planted as a result of the recommendations made by these Committees. It was evident that the Government, in view of the fact that imports of timber in sufficient quantities were coming into the country in a satisfactory manner, were not satisfied that a case had been made out as to the necessity of reafforesting the waste lands in the country. And the British public, in total ignorance of what forestry implied in the economy of the nation-a natural ignorance since the aims and objects of forestry formed no 
portion of a school curriculum-showed an entire lack of interest in the matter.

We have seen that it was four years only before the outbreak of the Great War that the Government, at length beginning to realize that forestry might in the future play some part in the industrial life of the people, added the subject as one of the branches to which the newly appointed Development Commission should devote its attention. During these four years the Development Commission, in conjunction with the Boards of Agriculture, as has been shown, did in effect devote some considerable attention to the forestry question. Forestry education was placed on a far better basis, the Universities and Agricultural Colleges throughout the country being accorded grants towards the improvement of their centres. Efforts were made to restart planting i work on a broader basis by offering grants on a profit-sharing basis to landowners, including Corporations, and so forth. In Ireland a State Forest Department came into being, and land was purchased for the purpose of afforestation. The outbreak of war, and the cessation of further grants from the Treasury, put an end to these activities.

The great difficulties experienced in providing the supplies of timber and pit wood absolutely essential to the carrying on of the war were discussed, and the small progress, which was inevitable, made with the object of furthering the afforestation question in these Islands, was dealt with.

With respect to the future, we first reviewed our present and future position as regards the provision 
of the timber supplies essential to the industries of this country. We then proceeded to deal with the afforestation problem itself in its various aspects.

We have seen that, carried out on the proper lines and under the expert guidance of properly qualified men with wide experience, it should, in combination with agriculture, greatly ameliorate the social conditions of the people resident in the areas of the country containing the poorer classes of soil. That it should lead to the resettlement on these areas in the future of a larger hardy population, enjoying to the full the amenities of life now demanded by the labourer.

That, so far as the nation is concerned, commercial forestry will result in the development of one side of its natural resources from which for a century and more but little benefit has been enjoyed. That, in addition, it will result in placing the nation in a position of security in the matter of its timber supplies in the event of war. It will decrease our total dependence on timber imports, and consequently give us some hold on the timber markets, thus eliminating our present position of total dependence on the foreigner. It will keep in the country a portion of the $£ 60,000,000$ to $£ 70,000,000$ which will have to be paid for these imports.

The intimate interdependence of Agriculture and Forestry was dealt with, the proper recognition of which, in the interests of the future afforestation schemes, is one of the first magnitude. It was shown that, unless the future afforestation problems are approached from the clearly enunciated basis, that 
agriculture is the main industry of the country-side, and that the new planting schemes are intended to dovetail in with and assist agriculture in the districts having the poorer soils, the success of the new industry will be gravely imperilled.

Some of the steps it will be necessary to take with the object of affording protection to the existing woods and new plantations from man, animals, birds (including game), and pests were then dealt with, and education in forestry briefly glanced at.

The important question as to whether State owned or privately owned forests would be preferable in this country was discussed, and the reasons against the former, on any extensive scale, adduced.

The present ownership of the land, and the nature of the land required for the future afforestation schemes were considered, and reasons given for the opinion held that by far the greater proportion of land required for afforestation should be acquired by either ordinary leasing or leases on a profit-sharing basis-the State only purchasing areas sufficient to enable it to demonstrate in different parts of the country that commercial forestry could be made to pay.

On the subject of the areas felled over during the war, it was held that as their owners had patriotically placed these areas at the disposal of the nation for war purposes, in all cases where the owner was not in a position to replant them, and since it is in the interests of national economy that they should be replanted at as early a date as possible, a case would a ppear to lie for the State affording assistance, 


\section{SUMMARY OF "CONCLUSIONS}

with sufficient safeguards, by way of grants to enable this work to be carried out

On the subject of the future afforestation schemes, the proposal of the Forestry Sub-Committee of the Reconstruction Committee to afforest an area of $I, 770,000$ acres, at a total cost of $£ I 5,000,000$, the amount of planting done during the first ten years being limited to 250,000 acres, at a cost of

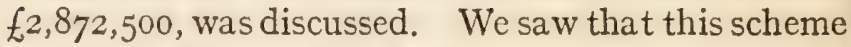
was framed during the war, and was based on the national safety margin, estimated for three years' war requirements.

With the war over, and the League of Nations become a question of practical politics, it was shown that there appears to be a case for the reconsideration of the reasons to be placed before the public for the urgency of undertaking the afforestation scheme, and the scale on which it should be carried out. And that these should be coupled with a clear realization of our position as regards future timber supplies, a point of serious moment to the industries of this country.

It was suggested that the whole matter should be approached from the view-point of the ultimate benefit which would accrue to future generations and to the nation, by initiating a policy on a basis which should make reasonably sure of fulfilling these objects-social and economic. That this aspect of the matter is of greater importance than starting from the rather rigid standpoint of the cost of the undertaking.

Finally, it was suggested that present generations 


\section{EMPLOYMENT FOR SOLDIERS I8I}

would obtain some return for the money expended, as forestry would provide congenial employment for those who have been fighting the country's battles, both officers and men, a proportion of whom have already expressed an intention of desiring to obtain open-air employment. If the pay and prospects offered under the new afforestation schemes are made sufficiently attractive, there should be no difficulty on the score of obtaining and training the staff required. And even if the terms offered were on the liberal side, the nation would only be repaying a part of the debt it owes to these men, and the extra rates offered them need not form a precedent in fixing the scale of salaries to their successors, or those who have not served actively in the war. 



\section{N D E X}

Afforestable land in Britain, IO 7,155

Afforestation, advantages of, in Britain, 107

- and a future national emergency in timber supplies, IOI, I63, I66

- and agriculture, I02, I05, I $12-2 \mathrm{O}$

- and British timber supplies, IOI

- and emigration, Ior

- and the rural population, IOI, I63

- and the waste lands in Britain, I0I, 108

- and the wintering grounds, I 56

- by leasing the land, 159

- in Britain, land required for, I 55-57

- in Britain, what it will do for the people, 10o

- its economic aspects in Britain, IOI, I63

- methods of acquiring land for, 152, I 57

- Midland schemes of, 43

- problem during the war, 69

- scale on which, should be undertaken in Britain, 165

- scheme in Britain, 8I, I66

- - suggested. Is scope sufficient? $169-70$

- schemes: conifers and hardwoods, 167,170

- - rate of planting, I68, I72 selection of the land, I73
Afforestation schemes, staff required, 173

- - suggested area to be planted, I67, I70, I7 $1, I_{72}$

- - suggested cost of, 168, 173

- - the, 162,166

- what it will do for the Nation, 106

Afforested area, protection of, 121

Agriculture and forestry, $\mathrm{IO}_{2}$, I05, II2-20

Arboricultural Societies, 3

Archangel and the northeastern Russian forests, 98

Assize of Woodstock, 20

Atholl larch woods, 30

Bark beetle danger in Britain, 73, 130

Black Country, the, 43

Black-game, damage to plantations by, 128

Boar, wild, 2 I

Capercailzie, damage to plantations by, 129

Catchment area, afforestation of Edinburgh Water, 48, 69

- - of Lanarkshire Water, 48,69

- - of Liverpool Water, $4^{8}$, 69

Chase, the, 18, 23

Commercial forestry, I06, I09, I I 5, I 50, I 57

- a key industry, $8 \mathrm{I}$ 
Commercial 'forestry, a new important national industry, 174

Commission, royal, on forestry, 41,165

Committees, Parliamentary, on forestry, $33,38,3$ ? 42

Conclusions, summaiy of, 175

Controller of timber, 55

Cooper's Hill, forestry training at, 39

Coppice with standards forest, 24

Court of Eyre, 20

Courts, forest, 20

Crown forests, 29, 34

Deer, fallow, 2 I

- forests, area of, 153

- red, 2I, I34

- roe, 21,134

Demonstration Forest Area, 42, 46, 145

Development Commission Act, 43,44

Development Commission and forestry, 44-9, 70, I59

- Commissioners and forestry education, 45, I4I

Disafforested tracts in Britain, their replanting, $16 \mathrm{I}, 17 \mathrm{O}$, I $7 \mathrm{I}$

Edinburgh, lecturer in forestry appointed at University of, 4 I

Education, forestry, $\mathrm{r}_{4} \mathrm{O}$

Education in forestry at Edin. burgh University, I I I

Epping Forest, 13, 21

Essex, Royal Forest of, I3, I8 Evelyn, John, and his planting campaign, 26, 27

Forest Charter, 20

- garden, the, 145

- industries, 8, 163

- of Dean, 13, 18, 20, 21, 34, $09,70,146$
Forest of Dean, Woodman's School at, 4I, I 44

- products, their use in domestic life, III

- trees, indigenous and introduced, 16

Forestry advisers, 45, 173

- and agriculture, 102,105 , I $12-20$

- and the Development Commission, 44-9, 70

- and the farmer, II 3

- and the forest labourer, $\mathrm{IO}_{3}$. 172

- British, decline of, 29

- - revival of, 32

- during the war, 51, 53

- education, 140

- in Britain, 2, 3, 13, 50, 67

- - future of, 77

- - in early times, 13,17

- - in later times, 23

- in Ireland, 49

- research work in British 130, 132, 146

- Sub-Committee of the Re. construction Committee, Report of, 162,166

Forests, destruction of, in Russian Western Provinces, 98

- direct utility of, 6

- indirect utility of, 8

- of Britain in Roman times, 14,15

- of the British Empire, 8I

- royal, 13, I7, 23

- disafforesting of, 20,2 $\mathrm{I}$, 22,23

- extension of, 17, 20

- Russian north-eastern, 98

- staff of royal forests, I9, 22

- the deer, 155

- utility of, to a nation, I, 4

Government and the afforestation question, $3,32,49,162$

- British, and a forest policy. 23, 24

Grazing lands, 195

Grouse and forestry, 129 
Hares, damage to plantations by, 127

High meadow woods, the, $\mathrm{I}_{4} 6$

Holding Act, Small, I I 6

Holdings, small, I9, I03, II619

Home-Grown Timber Committee, The, 54, 70, 74

House-building schemes in Britain, 80, II 9

Hylobius weevil, 72, I 30

Ireland, forestry in, 49

Land Acquisition Act, I 53

- area of afforestable land in Britain, 107,155

- for afforestation, methods of acquisition, I $52, I_{57}$

- in Britain, ownership of, I 52,153

-..required for afforestation, I55-57

Law, absence of a forest, in Britain, I2 I

- forest, in Norman times, 18

Leasing land for afforestation, I 59

Magna Charta, 20

Markets, requirements of British timber in early times, 25

Matches, shortage of supplies during the war, IIO

Murman port and North Russian forests, 98

New Forest, I3, I8, 21, 70

Nursery work (forest) during the war, $70,7 \mathrm{I}$

Oak tree defoliator, I3I

Paper, shortage of supplies during the war, III

Park, the, I 8

Peace Conference and League of Nations, $\mathrm{I}_{3}$
Pheasants and forestry, I33, I 37

Pit-wood supplies and the war, Planting, cessation of, in Britain, 27

- during the war, 69

- schemes in Britain, I04, I66

Protection of forests, I 2 I

- - against animal (mammal) pests, 124

- - - bird pests, 128

_- - domestic animals, I22, I23

- - - fire, 122

_- - game animals, I33

- - man, $12 \mathrm{I}$

- - noxious insects, 129

- - - plants and fungi, 132

Purlieu, 20, 23

Rabbits, damage to plantations by, 124

Reconstruction Committee, appointment of, during the war, 75

Salonika, the timber market of, 93

Scandinavian forests, 28

Sheep, acclimitisation problem, I 56

Sporting lands required for afforestation, I 55

State ownership of forest land, I 55, I 57

State versus private forests, ${ }_{14} 8$

Statute of Enclosure, 23

Statute of Woods, 24

Summary of conclusions on commercial forestry in Britain, I75

Sylva, Evelyn's, 25, 27

Teak, introduction of Moulmein, 28

Timber, British, decreased use of, 28,29 
Timber, foreign imports of, Timber supplies in France 28,49 , 10r, 108

- imports in $x 913,163$

- - in Britain, increase of, in the future, $165,17 \mathrm{I}$

- market of Salonika, 93

- - the Mediterranean and Near East, 93-7

- - the North European, 8793, 97

- requirements in future of Britain, $81,164,163$

- resources of America, 82, 83

- of Austria-Hungary, 8z, 93, 94

- of Belgium, 88, 92

- - ol Canada, 82,85

- - of Germany, 82, 88, 91

- of Newfoundland, 82,87

- - of Norway, $82,88,90$

- - of Rumania, 82, 93, 95

- - of Russia, 82, 88, 96, 98

- - of Sweden, 82, 88, 89

- of the Central Powers in November 1918 (Armistice), 80,82

- stocks in Britain at end of war, 68

- supplies and afforestation in Britain, IOI

- - and national safety, 25

- - during the war, and how we procured them, 53-68, I09

- - in Britain in November IgI8 (Armistice), 79

during the war, I5I

- - in France in November IgI8 (Armistice), 79, 80, 88, 92

- - our dependence on the foreigner for, 108

- - required for reconstruction purposes, $80,8 \mathrm{I}$

- - shortage of, 24

- Supply Department, the, 54. 80, I 44

Trafalgar, Battle of, and tim. ber supplies, 27

War, forestry during the, 5 , 33

Warren, the, 18 , 19

Windsor Forest, 13, 21, 34,

"Wintering" ground and afforestation, 156

Wolf, the, 21

Women, employment of, in forestry, $7 \mathrm{I}$

Woodlands, British, I, 106

- - and proprietors, 34

Woodman's schools in Britain, 4 I, I44

Woods, area of, in Britain, 34

- destruction of English, in seventeenth century, 25, 26

- systematic management of, 24

Woods, the soft, 30

Printed by Hazell, Watson \& Viney, Ld., London and Aylesbury, England. 



